\title{
New excavations at the Barbar Temple, Bahrain
}

Højlund, Flemming; Jensen, Pernille Bangsgaard; Hansen, Jakob; Haue, Niels; Kjærum, Paul; Lund, Dorte D.

Published in:

Arabian Archaeology and Epigraphy

Publication date:

2005

Citation for published version (APA):

Højlund, F., Jensen, P. B., Hansen, J., Haue, N., Kjærum, P., \& Lund, D. D. (2005). New excavations at the Barbar Temple, Bahrain. Arabian Archaeology and Epigraphy, 16, 105-128. 


\section{New excavations at the Barbar Temple, Bahrain}

In 2004 excavations at the Barbar Temple dating to c. $2000 \mathrm{BC}$ established that the function of the southeastern subterranean channel connected to the temple pool was to supply the pool with water and not to divert water away from the pool. North and west of the temple the oval terrace wall of its third phase was located. In the centre of the Northeast Temple the remains of a shaft-stairway leading down to a well-chamber was uncovered and shown to be furnished with two subterranean channels leading water into the chamber. South of the Northeast Temple a house with late pottery was excavated. Two stamp seals and two seal-impressed tokens were found.

Keywords: Bahrain, Dilmun, Barbar Temple, abzu, water channel, oval platform

\author{
Flemming Højlund, Pernille \\ Bangsgaard, Jesper Hansen, \\ Niels Haue, Poul Kjærum \\ and Dorthe Danner Lund \\ Moesgaard Museum, \\ Denmark
}

Flemming Højlund

Moesgaard Museum

DK-8270 Højbjerg

Denmark

E-mail: farkfh@hum.au.dk

\section{Introduction}

In the years 1954-62 a mound lying south of the village of Barbar on the north coast of Bahrain was excavated by the Danish archaeological expedition. It proved to contain three temples, following each other in time, the one built upon and around the other, and all dating to the centuries around 2000 $\mathrm{BC}$, when Bahrain was the centre of the Dilmun culture. Substantial parts of the first and the second temple were preserved and could be divided into four sub-phases - Temples Ia-b and IIa-b - whereas less is known about the third temple (III).

The architecture of the Barbar Temple consists of three main structural parts, most clearly seen in Temple II: 1) a high central platform with a double altar where sacrifices took place, surrounded by an oval platform, connected by 2) a processional staircase to a pool towards the west, a deep-lying chamber with fresh water, interpreted as the dwelling of the god (abzu), and by 3) a ramp leading eastwards to a court with abundant evidence of fire, where the sacrificed animals were cooked.

A related structure was identified and partly excavated to the northeast of the Barbar Temple under the designation of the Northeast Temple.

The excavations in the 1950s and 1960s at the Barbar Temple and the Northeast Temple have recently been published (1), and a number of questions that emerged from the preparation of this publication prompted a new excavation campaign that took place from January 30th-March 31st 2004 (2). The same horizontal and vertical coordinate systems were used in 2004 as in the old excavations.

\section{The water channels by the pool (693)}

In the south, west and north walls of the pool chamber were four openings for subterranean channels (Fig. 1), apparently water conduits, but it was unclear whether these channels brought water into the pool or away from it (3). In order to clarify this problem the continuation of the southeastern channel was investigated in two soundings during the 2004 campaign.

The first sounding was located c. $12 \mathrm{~m}$ southeast of the pool (Fig. 2.1) and here the channel was uncovered only $0.7 \mathrm{~m}$ from the ashlar oval terrace wall of Temple IIb. It is clear from the section (Fig. 3) that the channel was constructed in a large pit dug at a time when the area in front of the ashlar wall had accumulated to a surface level of $c$. 4.20. The base of the structure was set on subsoil sand at level c. 6.25 and consisted of two rows of well-dressed ashlars (Fig. 4), on top of which the walls were built of 


\section{F. HØJLUND ET AL.}

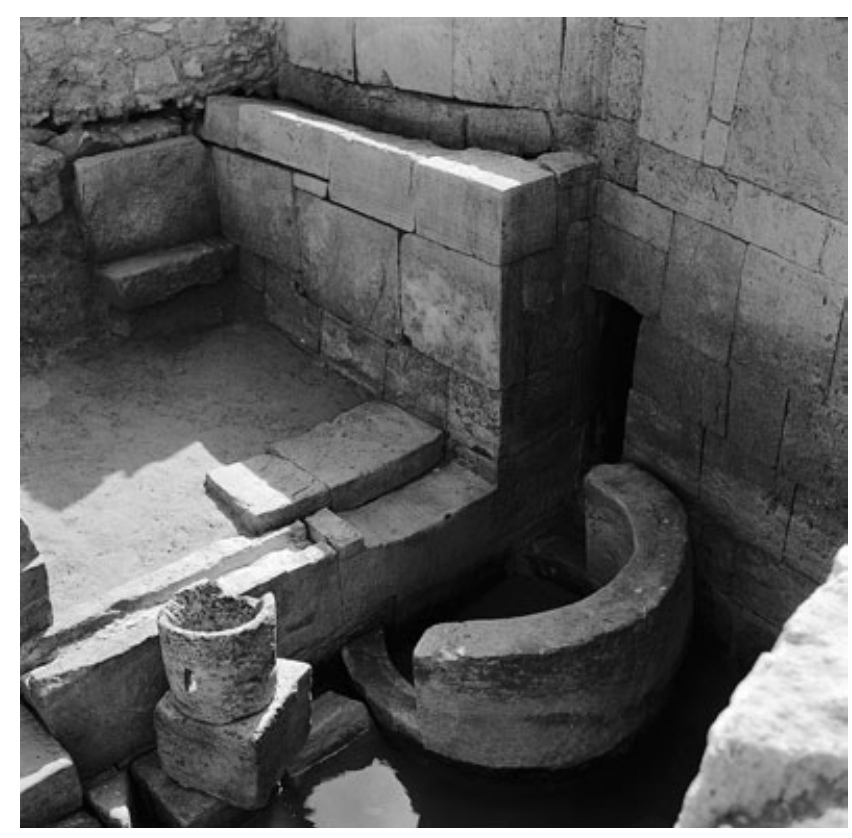

Fig. 1.

Barbar Temple pool with wall opening into the southeast channel, from the northwest (1960).

uncut stones, $20-30 \mathrm{~cm}$ across, laid in clay, the roof being made of particularly large undressed slabs, c. $65 \times 40 \mathrm{~cm}$. The inner height of the channel was c. $1.8 \mathrm{~m}$, and the distance between the walls at the bottom was $c .50 \mathrm{~cm}$. At mid-height the walls were only $15 \mathrm{~cm}$ apart, but this seems to be a result of subsidence. The floor of the channel, the interface between layers 27 and 8, consisted of subsoil sand with an uneven surface, perhaps hollowed out down to level 6.42 towards the north by the force of the running water. Above that the channel was almost completely filled with horizontal or slightly dished layers of sand, with some pottery of Temple $\mathrm{IIb}$ variety (4) (Figs 5-6). The pottery found in the layers surrounding the channel also dated to Temple IIb.

The second sounding was located $c .18 \mathrm{~m}$ southeast of the pool, at a distance of $2.7 \mathrm{~m}$ from the Temple IIb oval terrace wall (Fig. 2.2). Again the channel was built on subsoil sand, with two rows of well-dressed ashlars in a bottom course, on top of which the walls were built of uncut stones, $20-40 \mathrm{~cm}$ across, laid in clay, the roof being in this case made of well-dressed ashlars (Fig. 7). The inner height was only about $1 \mathrm{~m}$ and the distance between the walls $30-40 \mathrm{~cm}$. The floor of the channel consisted of subsoil sand at level 6.26, slightly hollowed, perhaps by the running water (Fig. 8). Above that, the channel was almost completely filled with horizontal or slightly dished layers of sand. No pottery was found inside the channel, but the layers surrounding the channel contained Temple IIb pottery.

From the opening into the pool, the first 4-5 m of the channel can be seen to be constructed entirely of well-dressed ashlars, built in bond with the walls of the pool chamber (Fig. 9). In 1959 the exterior of the channel was exposed from 2.5 to $5 \mathrm{~m}$ from the pool chamber and was here also constructed of well-dressed ashlars (5). The floor of the channel consisted of subsoil sand, slightly hollowed out, with a level of 6.61 for the first half metre. Between the channel and the pool was an ashlar 'threshold' with a surface at level 6.16, and directly above this threshold were two square holes cut in the walls, perhaps for securing some kind of sluicegate.

\section{Dating}

The walls of the channel are bonded into the walls of the pool chamber so that they must be the result of one and the same building phase. The pool chamber and therefore also the channel form an integral part of the latest phase of Temple II, i.e. IIb, which was covered up before the construction of Temple III. The channel was built in a pit cut into deposits accumulated in front of the oval terrace wall of Temple IIb and must therefore belong to an advanced phase of Temple IIb. The pottery found inside the channel and in the layers surrounding the channel can typologically also be dated to the time of Temple IIb.

\section{Conclusions and discussion}

The levels of the floor of the channel measured in the two soundings and at the opening into the pool (from SE to NW: levels 6.26, 6.42 and 6.61) make it clear that the floor slopes down towards the pool, i.e. it must have brought water into it. While there is no reason to doubt this conclusion, it nevertheless raises some questions.

If the channel was intended to fill the pool with water, why was the floor of the channel then level with the floor of the pool? It would surely have been more practical to have the channel outlet into 
BARBAR TEMPLE, BAHRAIN

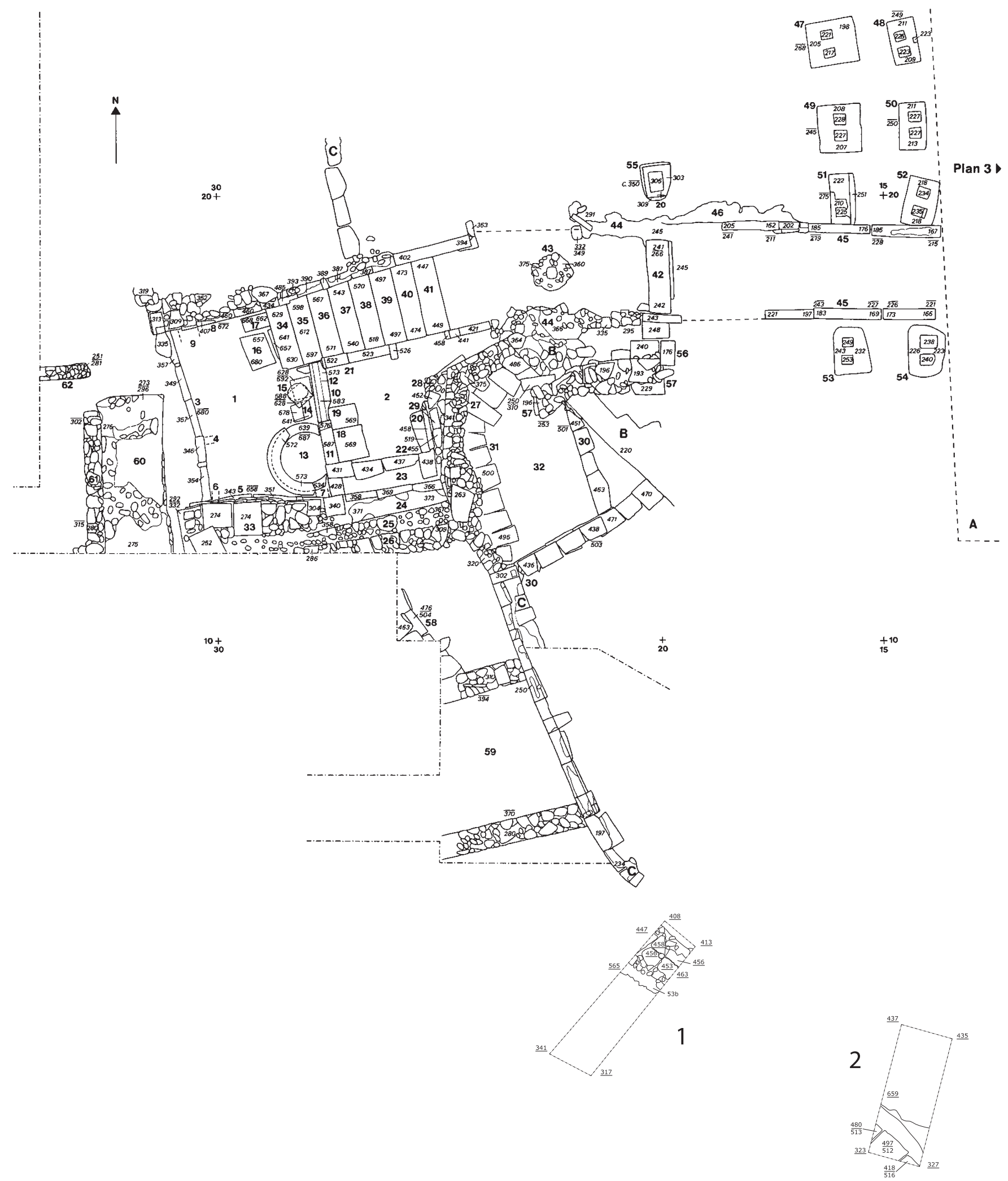

Fig. 2.

Plan of Barbar Temple pool with 2004 soundings of the southeast channel. 1: first sounding. 2: second sounding. 


\section{F. HØJLUND ET AL.}

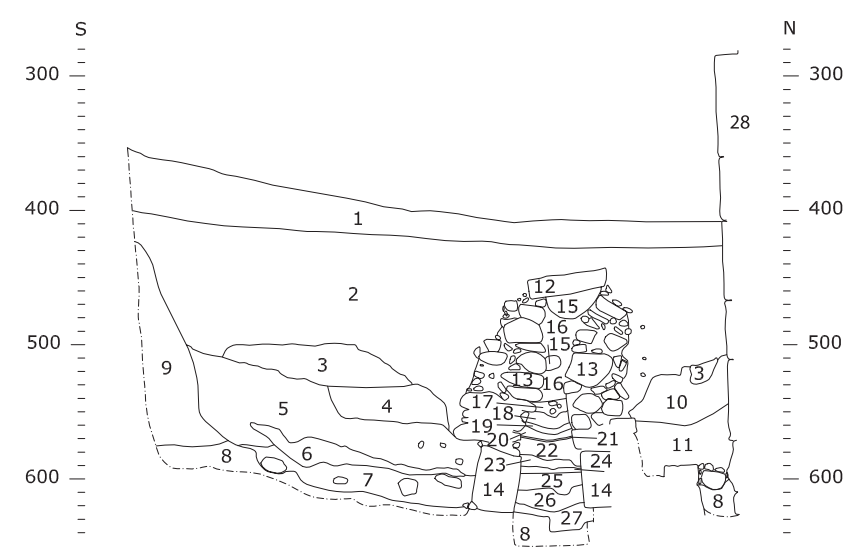

Fig. 3.

Section in first sounding of the southeast channel in front of Temple IIb oval ashlar wall. 1: light grey sand, probably deposited after excavation in 1959. 2: light greyish-brown sand. 3: light brown sand. 4: greyish-brown sand. 5: light greyishbrown to light grey sand. 6: yellow sand. 7: yellow-brown sand. 8: greenish-yellow sand, subsoil. 9: yellow sand. 10: greyishyellow sand. 11: light greyish-brown to light grey sand with many chippings of oolitic limestone, above up to $5 \mathrm{~cm}$, below up to $10 \mathrm{~cm}$ across. Between layer 11 and layer 8 some larger stones. 12: roof-stone. 13: uncut stones laid in yellow clay. 14: limestone ashlars. 15: cavity. 16: greyish-brown sand. 17: greyish-brown sandy clay. 18: light greyish-brown sandy clay. 19: dark grey sandy clay. 20: light greyish-brown sandy clay. 21: flakes of yellowish calcareous material. 22: dark grey clay with some bitumen. 23: light yellow-greyish clayey sand. 24: light greyishbrown sandy clay. 25: light yellow-greyish clayey sand. 26: dark grey clayey sand. 27: light brown-yellowish clayey sand. 28: ashlar oval terrace wall of Temple IIb.

the pool positioned above the desired water level of the pool instead of being level with its bottom! One reason for this might be that if the water had to be transported over a long distance the gradient of the channel would mean that the final stage of the channel had to be deep. The problem that this caused was perhaps solved by making a threshold between the channel and the pool; the water would then have to be lifted over the threshold into the chamber. A sluice-gate was possibly installed to raise even more the water level of the pool.

When the pool chamber was emptied of sand during the excavation in 1959, fresh water rose to a level of 5.62. In the temple well, $15 \mathrm{~m}$ towards the southeast, the subsoil water table was noted at 5.50 in 1957, and east of the temple the water table was measured at 5.55 in 1960 (6). All three measurements were taken in January-March.
On the ashlar walls of the pool chamber, in the third course from the bottom, there was a horizontal line at level c. 5.60, clearly to be seen on photographs from around 1960 (7), where the colour of the stone changes from slightly lighter above the line to slightly darker below, and where the ashlars seem to be especially eroded. This line was originally interpreted as traces of the ancient water level of the pool (8), but this may not necessarily have been the case, since it would mean that the third step of the stairs and the east chamber (9) were also flooded.

The two lowest steps of the staircase are severely worn, probably because they were often covered in water, since limestone is much more soft and susceptible to wear when wet than when dry. The third step is, however, completely without wear, and therefore it is unlikely to have been covered in water on a regular basis. The deep western pool chamber is divided from the staircase and the eastern chamber by a door at the second step continuing in a wall and a threshold (10), and it seems likely that the water was confined to the deep western chamber.

It is remarkable that the line of colour changes on the ashlar walls of the pool chamber should coincide exactly with the water level in 1959, and it makes one wonder whether these colour changes were caused by the recent, rather than the ancient groundwater level.

Irrespective of whether the groundwater table in ancient times lay at level c. 5.62 or below the third step at c. 5.90, of what use was then a channel with a floor that ended at level 6.61, i.e. $70-100 \mathrm{~cm}$ deeper? The decisive point may be that the groundwater table in arid regions like Arabia varies with season and changes from year to year depending on rainfall. The underground channels may thus be explained as a safety precaution, as a way of securing the presence of fresh water - vital to the cult - in the temple chamber, even in periods of severe drought.

Channels leading water into a well-chamber were also found in the 2004 excavations at the Northeast Temple (see below).

With the walls and roof of the channel constructed in stones set in clay, it seems strange that the floor merely consisted of subsoil sand without any fortification. The gradient of the floor is rather steep, 


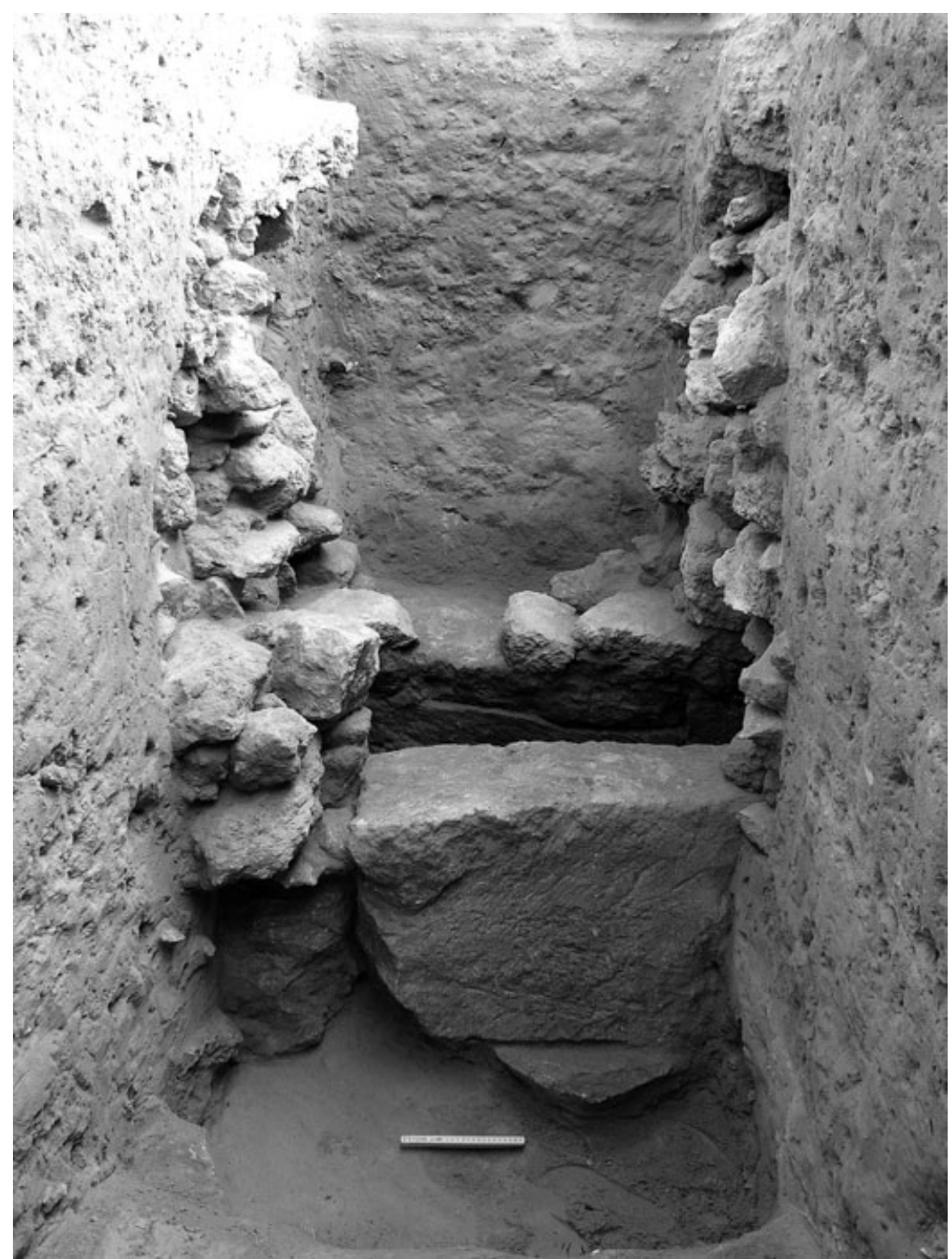

Fig. 4.

Southeast channel in first sounding, after removal of upper parts, from the south (2004).

$35 \mathrm{~cm}$ over $18 \mathrm{~m}$ or $c .2 \%$, so there would presumably be a danger that the running water would erode the sand below the walls with the risk of collapse. Besides, would the water not seep into the ground?

\section{The water channel east of the temple (693)}

In the 1960 and 1961/62 excavation campaigns, a subterranean channel rather similar to the one described above was located east of the temple. It was uncovered in two trenches and could be followed over a distance of $15 \mathrm{~m}$ (11). During the 2004 campaign the southernmost of the two trenches was reopened and two more trenches were excavated further south in order to determine the direction and gradient of the channel.

\section{Trench 7}

In the north trench opened in 1961/62 the floor of the channel consisted of long, c. $35 \mathrm{~cm}$-wide stones with a cut runnel in level c. 5.40 whereas no floor, either of stone or other material, was indicated on section 13 drawn in 1960 of the south 


\section{F. HØJLUND ET AL.}
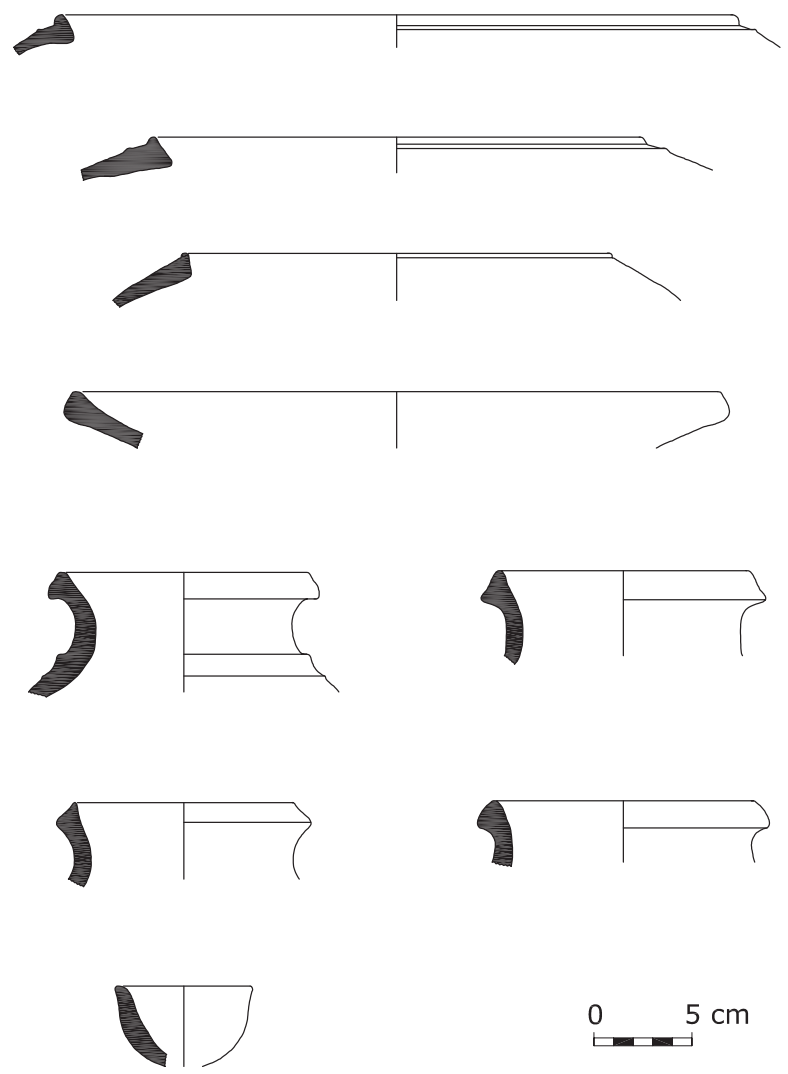

Fig. 5.

Pottery found in first sounding of southeast channel.

trench. A $3 \times 4 \mathrm{~m}$ trench was therefore opened in 2004 in order to locate this floor and to measure its level.

Underneath the modern surface at level 1.20 was a layer of fine sterile sand, interpreted as fill in a pit. Approximately $1 \mathrm{~m}$ below the modern surface, this pit cuts a thick black powdery layer of ashes containing sherds dated to Temple IIb (12). In the northern part of the trench both these layers were cut by the 1960 trench, and part of this refilled trench was emptied by machine in 2004. At the bottom of the almost 5 m-deep excavation, the subsoil underneath the channel was exposed at level 5.98. The walls of the channel were c. $60 \mathrm{~cm}$ apart, built of uncut stones and covered with large stone slabs. The floor of the channel was not made of stone, as in the section of the same channel made a few metres to the north in 1961/62. Instead, a c. $20 \mathrm{~cm}$-thick layer of moist clay, between level 5.98 and 5.78, marked the floor. Above the clay layer the channel had an inner

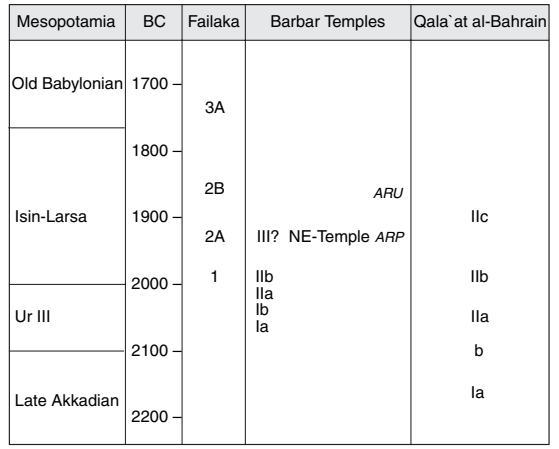

Fig. 6 .

Chronological chart for Barbar Temples I-III and the Northeast Temple.

height of c. $1.30 \mathrm{~cm}$, i.e. the same height as the channel a few metres further north, and it was filled with thin horizontal layers of sand. The walls of the deep trench were too unstable to allow the section to be drawn.

\section{Trench 5}

Approximately $16 \mathrm{~m}$ south of trench 7 , the channel was again uncovered in a $5 \times 3 \mathrm{~m}$ trench orientated east-west. The south section of trench 5 is seen in Figure 10. The walls of the channel were built of uncut stones, $15 \times 30 \mathrm{~cm}$ across, laid in clay and covered by large stone slabs, $0.6 \mathrm{~m} \times 1 \mathrm{~m}$ and c. $25 \mathrm{~cm}$ thick, tightened with plaster (Fig. 11). The channel is constructed in a narrow pit which cuts layers 25-30 (Fig. 10). The pit was back-filled again with layers 10-14 and thereupon accumulated a thick layer (layer 9) of dark grey, powdery ash with many potsherds datable to Temple IIb (Fig. 12) and a grinding-slab (Fig. 13). The layer also contained small chippings of oolitic limestone, remains from the final shaping of the temple ashlars (13). In the southwest corner of the trench layer 9 was disturbed by a sandy pit, layers 7-8, which contained fragments of two Islamic pots with some resemblance to shapes found in the Early Islamic deposit in the Barbar well (Fig. 14) (14).

Four roof stones were exposed, but to the north, one was missing, and the special circumstances of this area are documented in the north section (Fig. 15). The same general picture of construction and covering of the channel is seen as in Figure 10, but after the deposition of layer 5 (= layer 9 in 


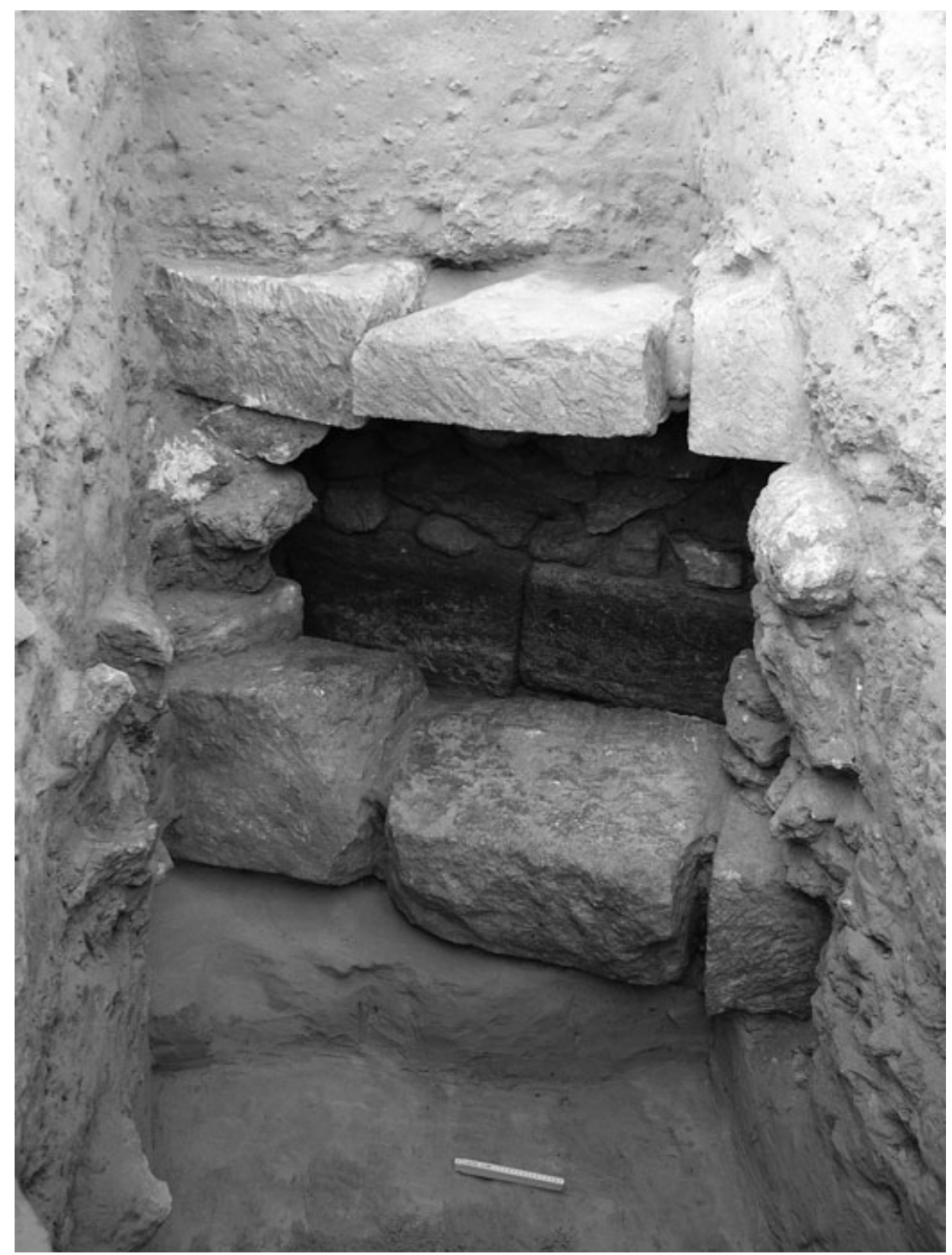

Fig. 7.

Southeast channel in second sounding, from the north, after removal of the northern wall (2004).

Fig. 10) a shaft was dug through this layer down to the channel. This shaft was noted already at level 2.25 when the trench was being excavated. The shaft was later filled up with layers $15 \mathrm{ff}$.

After the roof slabs and the west wall of the channel had been removed, a north-south section was dug through the layers deposited inside the structure (Fig. 16). The floor of the channel consisted of two layers of clay 7-8 (= layers 22-23 in the south section, Fig. 10) sloping slightly from north (level 5.60) to south (level 5.64). The clay was homogeneous, fine, moist and very plastic, with no signs of layering. In short nothing indicated that this clay was deposited by water during the use of the channel, and it is therefore interpreted as an attempt to produce a waterproof floor. Layer 6 is interpreted as deposited by water on the floor.

In the northern part of the section is a disturbance of layers 6-8, filled with layers 9 and 10, and this disturbance should probably be related to the shaft described above, which reached the channel exactly at this location. Layers 1-5 must then be even later layers. 


\section{F. HØJLUND ET AL.}

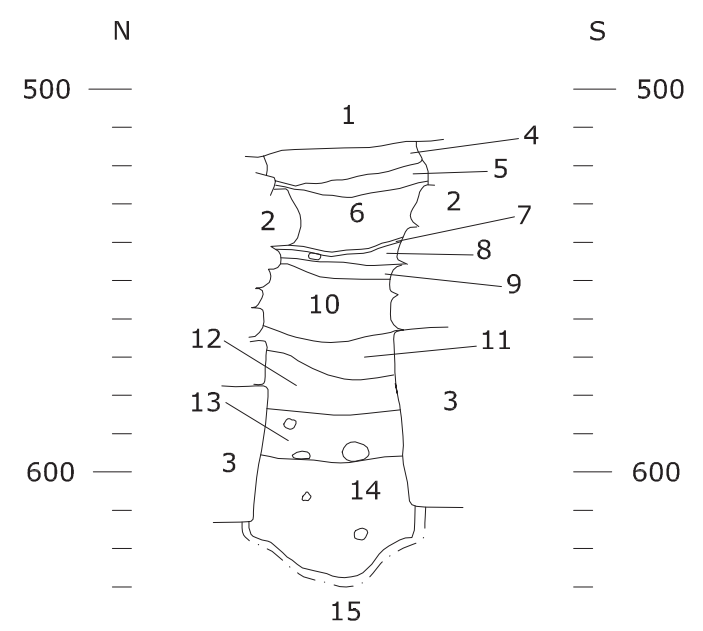

Fig. 8.

Section in second sounding of the southeast channel. 1: roofstone. 2: uncut stones laid in yellowish-brown clay. 3: limestone ashlars. 4: cavity. 5: greyish-brown clayey sand. 6: yellowishbrown clayey sand. 7: flakes of yellowish calcareous material. 8: yellowish-brown clayey sand. 9: dark brown clayey sand. 10: yellowish grey sand. 11: greyish-brown clayey sand with some bitumen. 12: dark brown clay. 13: yellowish-grey sand. 14: dark yellowish-grey sand. 15: greenish-yellow sand, subsoil.

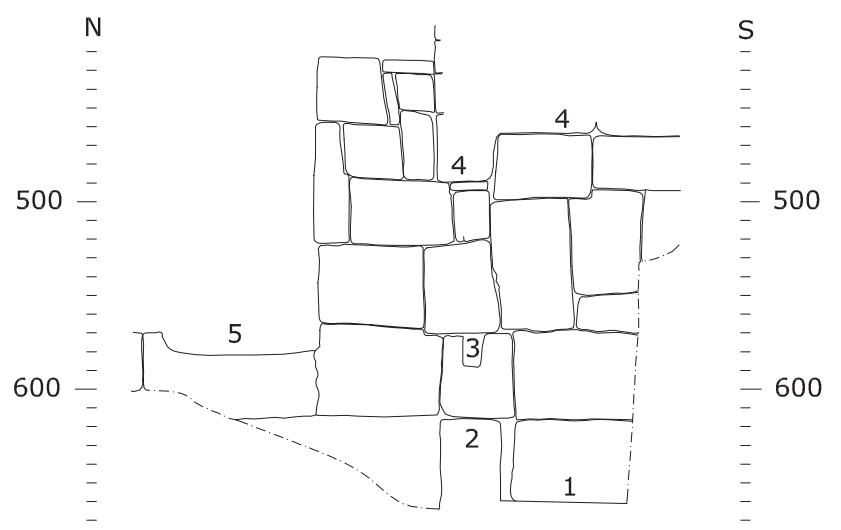

Fig. 9.

Elevation of east wall of the southeast channel built in bond with the pool chamber wall. 1: floor in channel. 2: 'threshold' between channel and pool chamber. 3: hole cut in wall, for securing sluice-gate? 4: roof of channel. 5: threshold between east room and west room in pool chamber.

Also in the stretch of channel uncovered in the north trench opened in 1961/62, a stone was missing in the roof, considered to allow for cleaning (15) and in the proximate section 12 it is noted that layer 26 cuts through the dark powdery (ashy) layer $21-$ a good parallel to the circumstances in Figure 15. Similarly, a sand-filled pit cutting the dark ashy

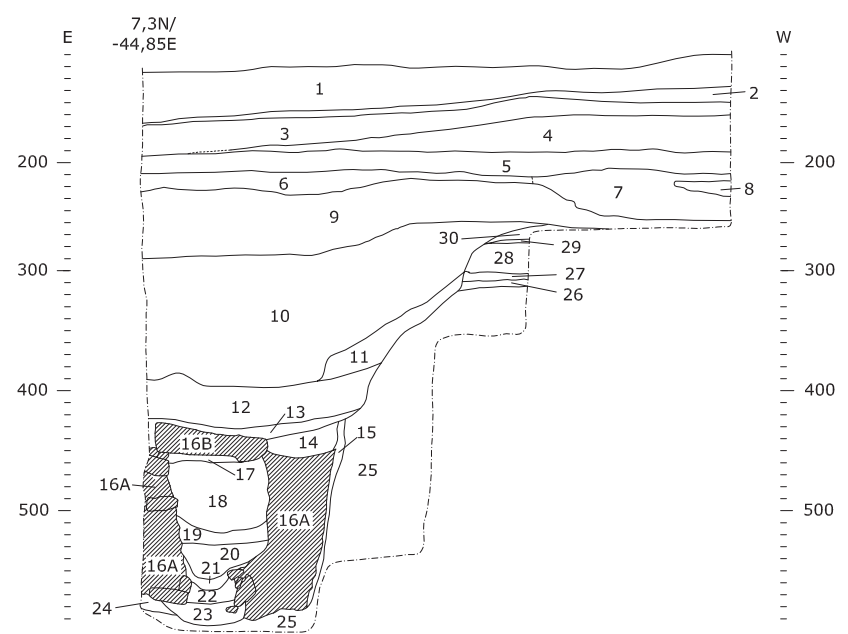

Fig. 10 .

South section through channel in trench 5. 1: light grey to greybrown sand with scattered small stones and plaster rubble. 2: dark grey-brown sand with scattered small stones and plaster fragments. 3: as 1. 4: grey to grey-brown sand with scattered small stones and plaster fragments. 5: light grey to light greybrown sand. 6: sterile light brown sand. 7: sterile light brown sand with scattered lumps of dark grey-brown sand. 8: dark grey-brown sand. 9: dark grey, powdery ash with small oolitic limestone chippings and potsherds. 10: grey to light grey-brown sand with lumps of compressed sand. 11: grey to light greybrown sand. 12: horizontal layers, $5-8 \mathrm{~cm}$ thick, of brown and dark grey-brown clayey sand. 13: dark grey to black clayey sand. 14: brown to light grey sand. 15: fine light grey-brown sand. 16A: uncut stones, 15-30 cm across, laid in clay. 16B: roof-stone. 17: cavity. 18: many thin layers of sand. 19: many thin layers of clayey sand, darker than 18. 20: layers of grey-brown sand. 21: dark grey-brown sandy clay=layer 6 in Fig. 16. 22: grey clay = layer 7 in Fig. 16. 23: dark grey clay with small pieces of charcoal = layer 8 in Fig. 16. 24: fine light grey-brown sand. 25: sterile, light yellow sand, subsoil. 26: fine, light grey-brown sand. 27: light grey to light grey-brown sand. 28: dark brown clayey sand. 29: plaster. 30: grey-brown to brown clayey sand.

layer datable to Temple IIb was noted in trench 7 . Perhaps we have here evidence of three access-holes with an internal distance of $15-16 \mathrm{~m}$. The fact that these possible cleaning-shafts do not contain dark ashes indicates that they postdate the use of the Eastern Court of Temple II.

\section{Trench 6}

The continuation of the channel was located $7 \mathrm{~m}$ to the south in a $15 \mathrm{~m}$ long and $65 \mathrm{~cm}$ wide, east-west oriented trench, dug by machine. The top of the roof stone was measured to level 4.55. In the northern section of the trench a narrow, hollow space was 


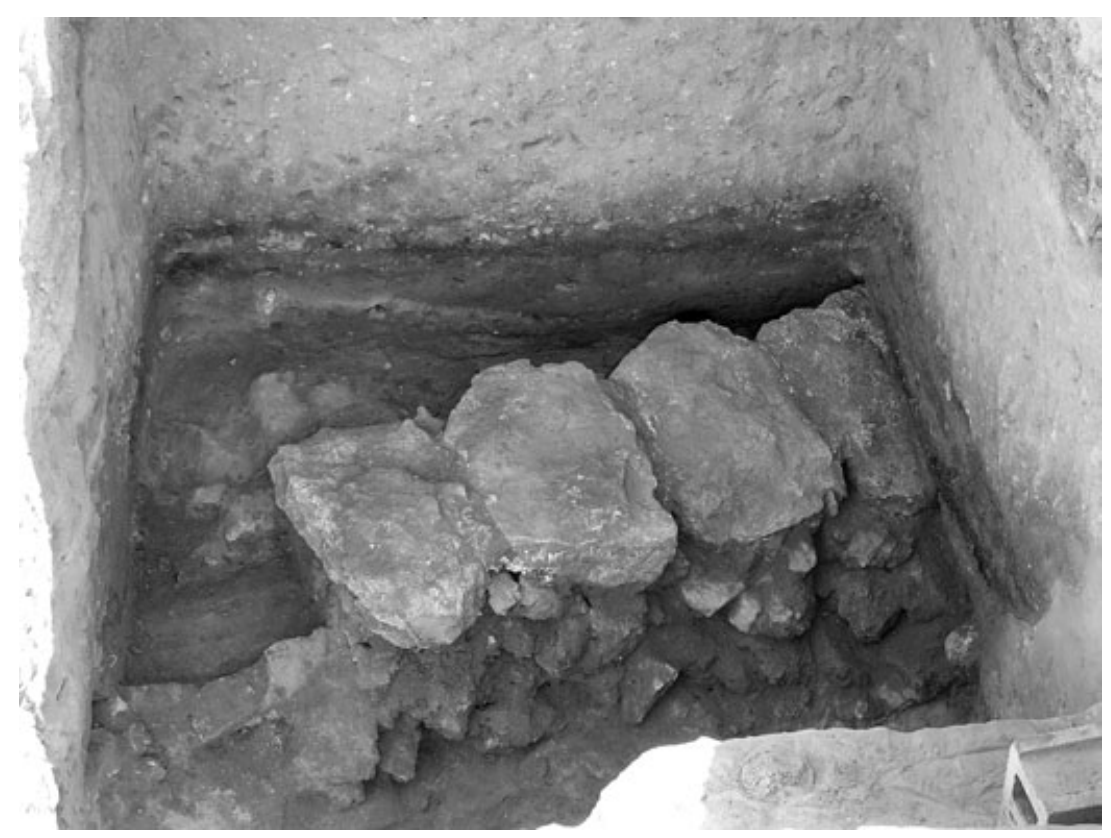

Fig. 11 .

Stone slabs covering channel in trench 5, from the west (2004).

noted below the roof stone. The pit dug for the channel was $4.5 \mathrm{~m}$ wide at the top and was filled with a layer of dark grey sand, followed by a layer of black powdery ash, similar to layer 9 in the south section of trench 5. At the bottom the pit was approximately $1-1.5 \mathrm{~m}$ wide and filled with brown sand. The brown sand is interpreted as back-filling material from the construction of the channel and the black layer as ashes from the Eastern Court of Temple IIb. The partly filled-in ditch would then originally have been visible south of the temple and only over time have been filled with ashes from the Eastern Court.

\section{Dating}

The channel east of the temple is everywhere covered by a $40-60 \mathrm{~cm}$-thick, dark layer of ashes with an upper level of c. 2.20 in trenches 7 and 5 . The layer contains numerous potsherds datable to Temple IIb, and the ashes undoubtedly originate from the Eastern Court (16). The excavators in 1960 and 1961/62 noted that the channel was overlain by the wall of the Eastern Court and therefore earlier, but the channel could possibly also have been built together with a reconstruction of the Eastern Court.

\section{Conclusion and discussion}

The channel east of the Barbar temple was originally uncovered in 1960 and in 1961/62. In 2004 its southward continuation was located in trenches 5, 6 and 7 running in a straight line from northnorthwest to south-southeast. The level of the roof stones falls evenly from 3.82 in the north to 4.55 in the south, i.e. $73 \mathrm{~cm}$ over $33 \mathrm{~m}$, or c. $2 \%$. The levels of the floor are more uneven, but there is a general slope towards the south, from 5.45 in the north, over 5.78 and 5.59 to 5.64 , i.e. $20 \mathrm{~cm}$ over $27 \mathrm{~m}$, or c. $0.7 \%$. There can therefore hardly be any doubt that the channel was designed to bring water from a place north of the temple towards the south. At its most southerly position the channel was constructed in a c. 4 m-deep pit, and it is doubtful how much further it would have proceeded, because of the practical difficulties of constructing at this depth.

The origin of the water north of the temple and the purpose of transporting it towards the south are unknown. Is this channel perhaps connected to the southeast pool channel described above or is it part of an irrigation system - an early example of a falaj? In order to answer these questions it would be helpful if the subterranean structures could be 

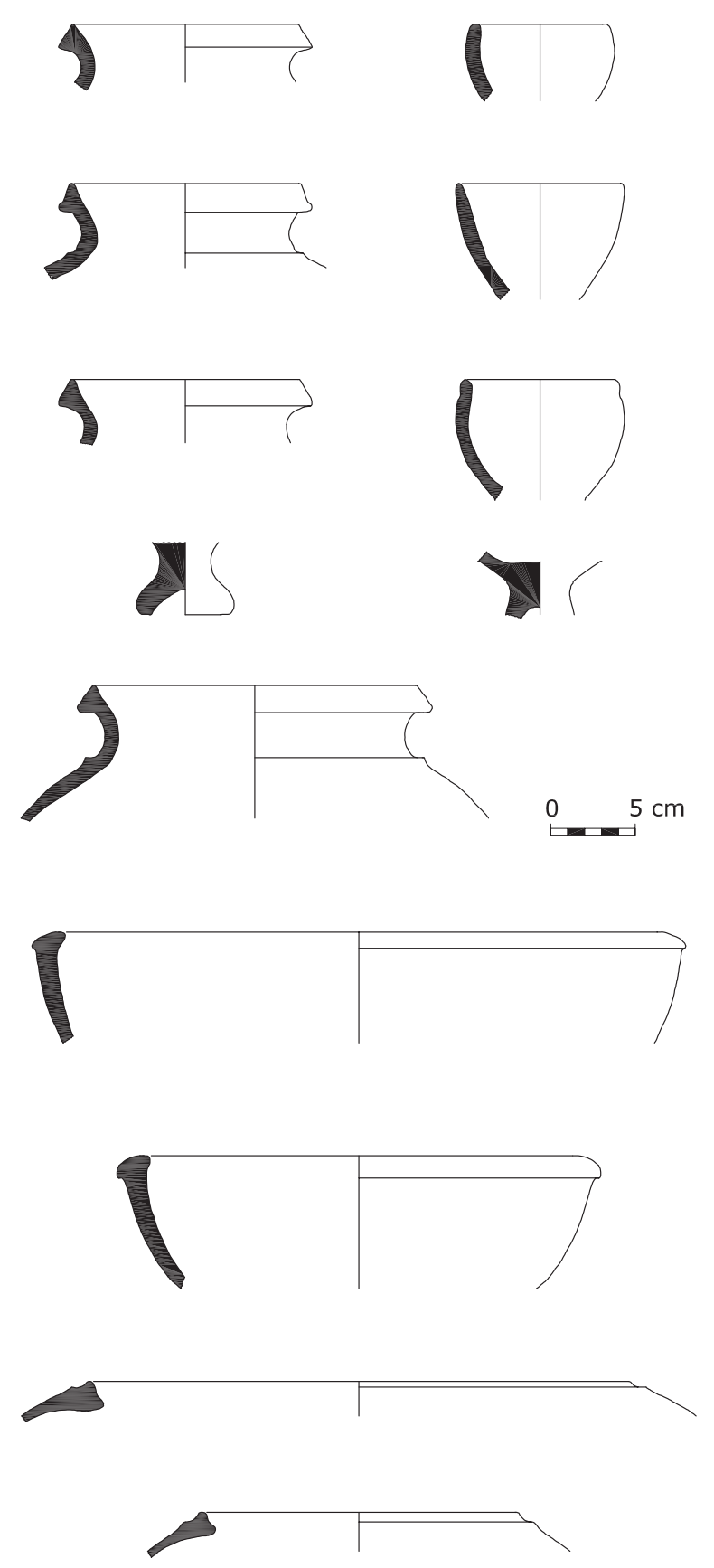

Fig. 12.

Pottery from layer 9 in the south section of trench 5 .

detected by geophysical methods, but experiments in 2004 with ground-penetrating radar and conductivity meter proved unproductive (17).
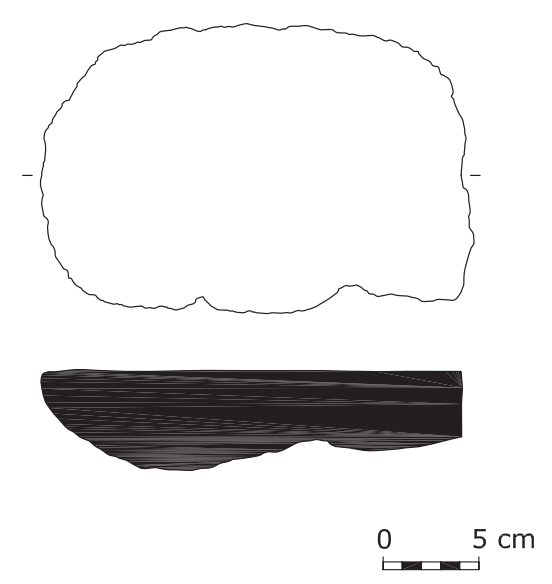

Fig. 13.

Grinding-slab from layer 9 in the south section of trench 5 .
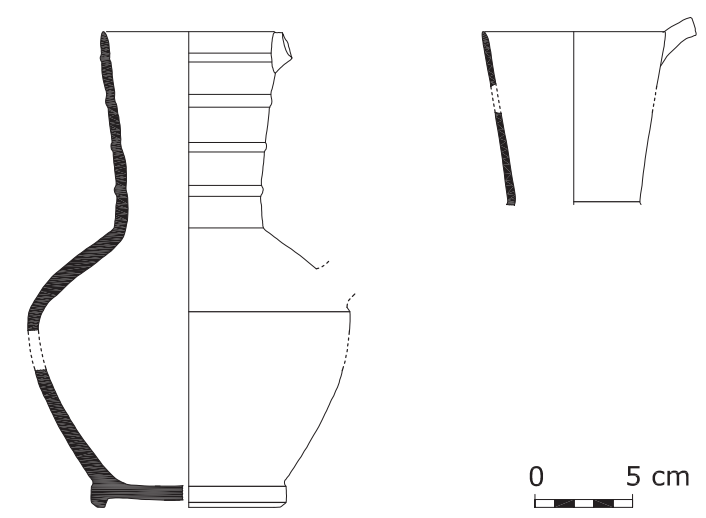

Fig. 14.

Islamic pottery from the upper layers of trench 5 . Neck part in fine, yellow ware and jar with yellowish surface and reddishyellow ware.

\section{Sounding south of the Eastern Court (693)}

A c. $5 \mathrm{~m}$-long sounding was dug in continuation of the north-south running part of the old section 14 (18), reaching $-6.5 \mathrm{~m} \mathrm{~S}$. At $-6 \mathrm{~m} \mathrm{~S}$ and at level $3.66 \mathrm{a}$ stamp seal was found with Temple IIb pottery.

Stamp seal no. $693 \times 1$ (Fig. 17). Disc profile concave, grey steatite, white-glazed. On the reverse three lines and four circles. Diameter of the obverse $25 \mathrm{~mm}$, diameter of the boss $20 \mathrm{~mm}$, total height $14 \mathrm{~mm}$, disc height $8 \mathrm{~mm}$.

The motif belongs to the numerous group where only animals are depicted, here a leaping lion, with claws, wide-open toothed jaws and sigmoid tail, followed by an antelope. Above the scene a snake with wide-open toothless jaws. The scales of the snake 


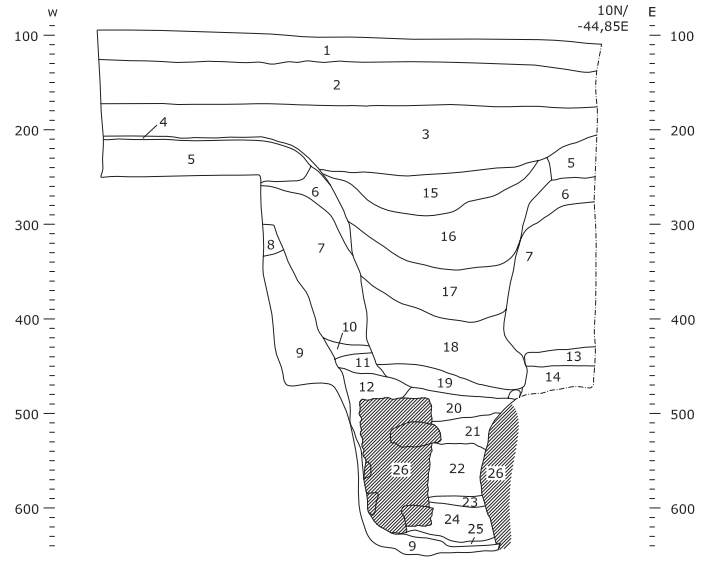

Fig. 15.

North section through channel in trench 5. 1: light grey-brown sand with scattered small stones and plaster rubble. 2: greybrown sand with scattered small stones and plaster rubble. 3 : sterile light brown sand. 4: oolitic limestone chippings. 5: dark grey powdery ash with oolitic limestone chippings and pottery. 6: as 5, but lighter grey. 7: light grey-brown sand with lumps of compact sand. 8: as 5. 9: light yellow sterile sand, subsoil. 10: fine, light grey-brown sand. 11: light grey-brown sand. 12: fine, light grey-brown sand. 13: dark grey clayey sand. 14: grey-brown sand with small stones. 15: sterile light-brown sand with small stones. 16: light-brown alternating with grey-brown layers of sand. 17: light-brown alternating with grey layers of sand. 18: grey sand. 19: dark grey-brown sand with small stones. 20: light grey to brown sand. 21: light to dark grey-brown sand with small stones. 22: scattered stones in grey-brown sand. 23: grey sandy clay with thin layer of charcoal at the top. 24: light grey-brown sand. 25: light grey-brown sand. 26: uncut stones, $15-30 \mathrm{~cm}$ across, laid in clay.

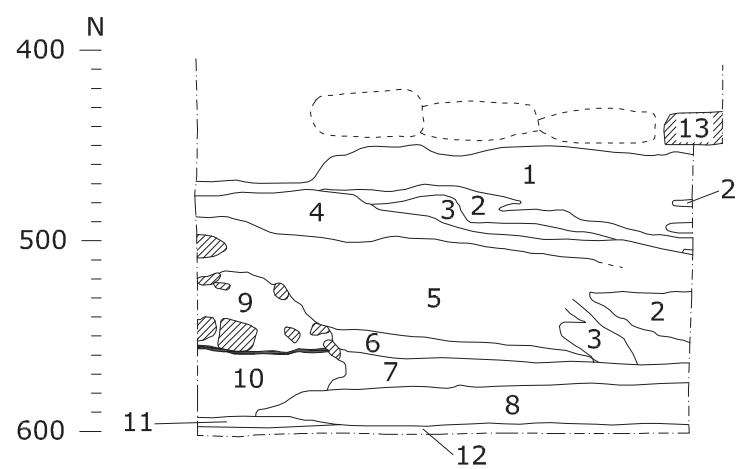

Fig. 16.

North-south section through the layers filling the channel in trench 5. 1: light grey-brown sand. 2: light greyish-yellow sand. 3: grey-brown clayey sand mixed with greyish-yellow sand. 4: greybrown clayey sand. 5: dark grey-brown clayey sand. 6: dark greybrown sandy clay. 7: grey clay. 8: dark grey clay with small charcoal pieces. 9: light greyish-yellow sand with small stones. 10: homogeneous grey-brown clayey sand with thin layer of charcoal at the top. 11: thin, 2-15 mm thick, layers of grey and grey-brown sandy clay. 12: sterile light yellow sand, subsoil. 13: roof-stone.
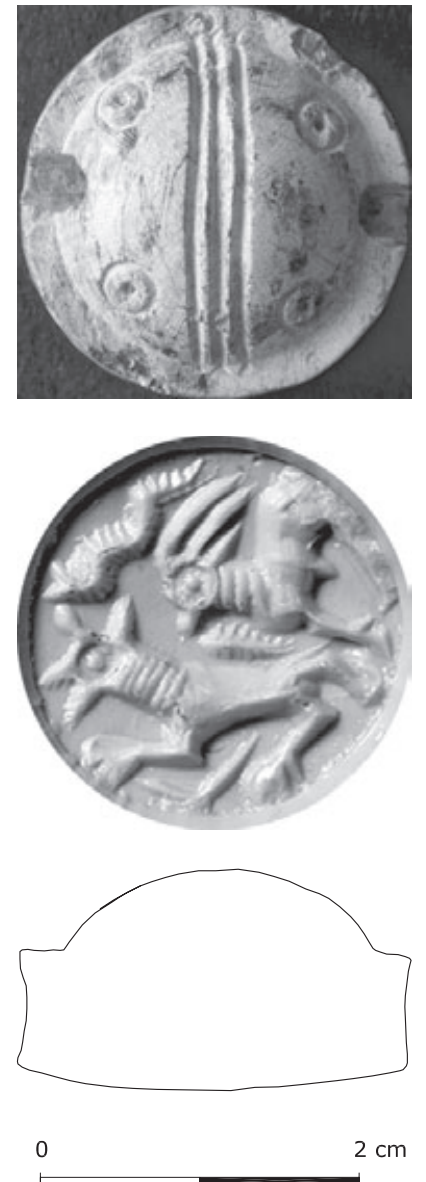

Fig. 17.

Dilmun stamp seal of style $1 \mathrm{~A}$.

are indicated with close incisions from both sides. Between the lion and the gazelle a palm frond. Below the lion an angular figure - probably a crescent.

The well-fed ruminants and the scaly snake are typical of style $1 \mathrm{~A}$ and similar to the animals on seals from period IIb-c in Excavation 520 at Qala'at al-Bahrain and from Saar Settlement (19).

\section{The Temple III oval platform and well chamber (692)}

The third phase of the Barbar temple was the latest and lying uppermost, and therefore also the first and most severely plundered for its valuable stone material. The earlier and deeper lying temples, I and II, were much better preserved, and continuity between the structure and functions of these two main phases could therefore be extensively documented (20). Because so little of Temple III was 


\section{F. HØJLUND ET AL.}

preserved, it has been possible to question the degree of continuity between Temples II and III: in particular, the apparent lack of an oval platform, an Eastern Court and a well chamber in Temple III have been noted as possible signs of changes in the cult (21). In order to investigate these problems a northsouth sounding was made in 2004 at the northern edge of the temple.

\section{Temple III oval platform}

The north-south sounding was placed between two sections from the old excavations, the Main Section (section 19) and section 31, right between the two plinth-stones north of the Temple III platform (22). The sounding began in $53.3 \mathrm{~N}$ and ran almost $25 \mathrm{~m}$ to the north (Fig. 18).

At the edge of the mound, c. $58 \mathrm{~m} \mathrm{~N}$, a thick layer (layer 6) of plaster and stones was uncovered, $1.9 \mathrm{~m}$ wide, with a base level of 2.78 and a top level of 2.14. This is interpreted as the foundation of a wall, plundered by means of pit 3 , cutting through layer 4 and leaving a layer (layer 5) of sand with much plaster rubble on top. The same foundation layer of plaster and stone was recorded with similar levels in the old Main Section and was followed for $12 \mathrm{~m}$ towards the west-southwest (23). In the old section 31 deep diggings (plundering) can be seen in the probable position of the wall (layers 2-3).

In the primary publication this wall/foundation was interpreted as a continuation of the northwest oval terrace wall of Temple IIb (24), but the building technique and the levels are too different for that to have been the case. The oval wall of Temple IIb is in its northwest occurrence built of uncut stones, laid in clay; it is quite thin, $30-45 \mathrm{~cm}$ wide, has base levels of $c$. 3.10-3.25 and is preserved only to a height of $10-20 \mathrm{~cm}$. Conversely, the wall/foundation discussed here is constructed of stone and plaster fragments with clay and plaster as mortar and especially with light brownish plaster occurring in large horizontal sheets. It is much broader, in some places more than $2 \mathrm{~m}$, and has a base level at 2.78 and top levels at 2.12-2.40 (25).

As will be shown below, the surface of the Temple $\mathrm{IIb}$ oval platform is in the North-South Section indicated by layers 7 and 10, and layer 4 must be interpreted as oval platform fill of Temple III bounded by a now plundered terrace wall standing on the

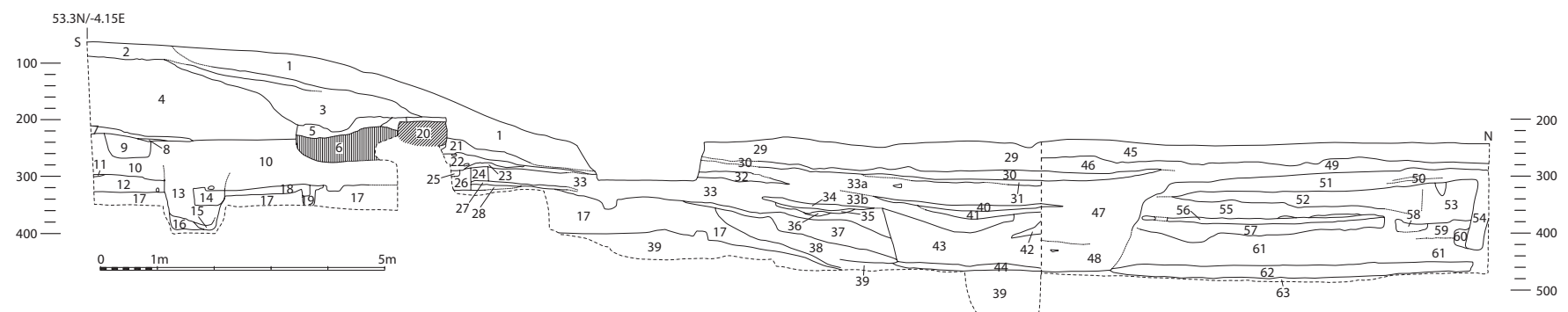

Fig. 18.

North-South Section north of the temple, compounded of several separate sections. 1: sand, stones and plaster rubble, spoils from early excavations. 2: yellow-brown sand with many stones and plaster rubble. 3: grey-brown sand with scattered lumps of plaster. 4: greyishbrown sand with scattered lumps of clay. 5: grey-brown sand with much plaster rubble. 6: stones in plaster. 7: powdery, dark greybrown ashes with charcoal and burnt bones. 8: sand and ash. 9: yellow sand with lumps of plaster. 10: grey-brown clayey sand with lumps of clay and plaster. 11: clay. 12: brown to grey-brown sandy clay. 13: light grey-brown clayey sand. 14: dark grey-brown ash and charcoal. 15: brown to grey-brown sandy clay. 16: grey-brown clayey sand with lumps of clay and plaster. 17: sterile yellow sand, subsoil. 18: light grey-brown sand. 19: light grey-brown clayey sand. 20: circular stone with central hole. 21: light brown sterile sand. 22: light brown sandy clay with few stones. 23: dark brown sandy clay. 24: light brown clayey sand. 25: light brown clay. 26: grey-brown clayey sand with lumps of clay and plaster. 27: rather dark brown sandy clay. 28: grey-brown clayey sand with lumps of plaster. 29: light brown sand. 30: grey-brown clay. 31: grey-brown sandy clay. 32: dark grey sand with plaster and bitumen. 33: grey-brown sand with patches of clay and plaster. 34: grey-brown clay. 35: very dark sandy clay. 36: grey sand. 37: dark brown sandy clay with charcoal. 38: dark yellowish-brown sandy clay. 39: greenish-gray sand with lumps of compressed sand, subsoil. 40: shells. 41: dark clay with stripes of light sand. 42: grey sand. 43: yellow brown sand. 44: yellow sand. 45: light brown sand. 46: yellow-brown sand. 47: almost sterile yellow sand. 48: almost sterile brownish-yellow sand. 49: yellow-brown sand. 50: brown-black soil. 51: dark brown soil. 52: grey-brown sand. 53: grey sand. 54: dark-brown soil. 55: grey-brown sand with lumps of clay. 56: light brown clay. 57: brown to grey-brown clayey sand. 58: small stones laid in plaster. 59: grey-brown sand with lumps of clay. 60: dark-brown soil. 61: grey-brown sand. 62: dark brown soil. 63: light grey sand with lumps of compressed sand. 


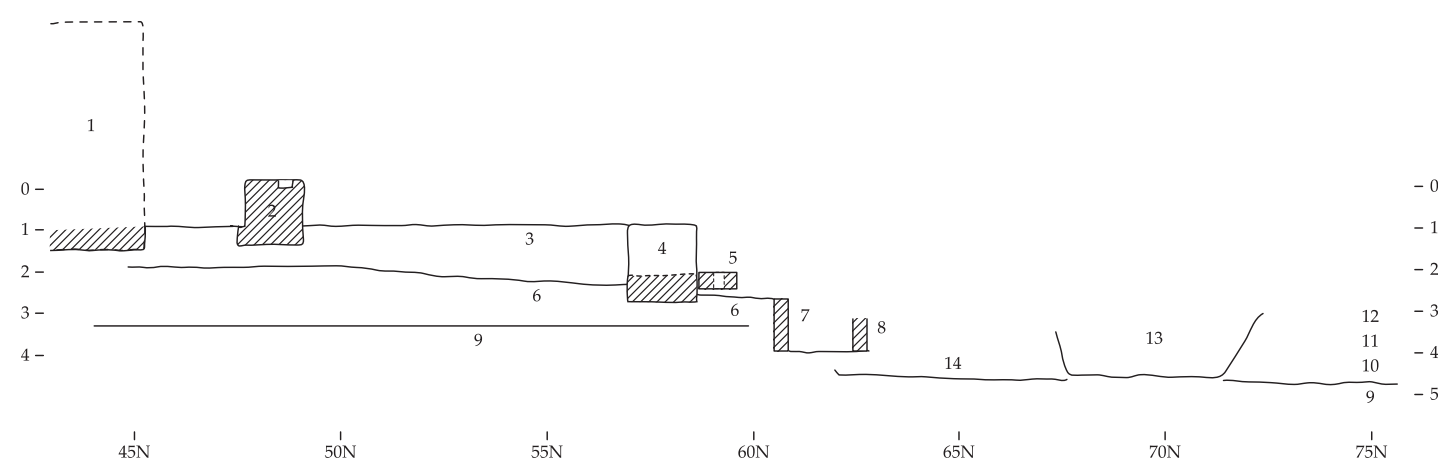

Fig. 19.

Interpretation of North-South Section north of the temple (Fig. 18). 1: northern terrace wall of Temple III. 2: plinth stone north of the central platform of Temple III. 3: minimum height of oval terrace of Temple III. 4: oval terrace wall of Temple III. 5: round stone block with central hole. 6: oval terrace of Temple IIb. 7: oval terrace wall of Temple IIb. 8: north wall in semicircular structure attached to 7. 9: subsoil sand. 10: layers dating to Temple I/IIa. 11: layers dating to Temple IIa. 12: layers dating to Temple IIb. 13: huge pit cutting 10-12, along the North-South Section. 14: bottom of huge pit east of the North-South Section.

foundation 6 (Fig. 19.4). The massive occurrence in the east-west running foundation of light brown plaster is a prominent feature of Temple III walls (26).

The platform fill of Temple III, layer 4, reaches up to level 90 in the North-South Section and the corresponding layer 4 in the old Main Section to level 80 (27). This would indicate a minimum top level for the surface of the oval platform, which is supported by the fact that the largest plinth-stone is completely evenly finished on the outer sides, with the exception of a rough and irregular footingportion in level 90, which was presumably set into the ground (28). This gives a height of the terrace wall, including the foundation, of $1.90 \mathrm{~m}$. The distance to the central platform is c. $13 \mathrm{~m}$ (Fig. 19).

About 12 m east of the North-South Section a new trench was dug in 2004 in order to trace the continuation of the Temple III oval terrace wall. In the nearby old section 31 the wall itself has disappeared, leaving a well-defined robbers' pit with the centre in $58.2 \mathrm{~m} \mathrm{~N}$ (29), and the same appeared in the new section, this time with the centre of the robbers' pit in $59.4 \mathrm{~m} \mathrm{~N}$. The bottom of the pit is at level 2.70, corresponding to the base of the foundation further west. On both sides of the robbers' pit were thick layers of oolitic limestone chippings, residue from the final dressing of the ashlars of the terrace wall. A similar occurrence of oolitic chippings was noted in 2004 at the base of Temple IIb's ashlar wall (Fig. 3.11), and it is interesting to note that there, the lowest-lying chippings measured up to $10 \mathrm{~cm}$ across, whereas the upper- most chippings only measured up to $5 \mathrm{~cm}$, indicating a first rough dressing followed by a fine one.

Another stretch of wall of similar dimensions, levels and building technique, excavated in 1959 west of the pool (30), can now be interpreted as the foundation for the western terrace wall of Temple III. The distance to the central platform is in this case c. $14 \mathrm{~m}$. Whether the lower platform of Temple III was oval or round is not possible to ascertain before further excavations are made east of the temple, and this actually also applies for the lower platforms of Temples I and II!

\section{Temple IIb oval platform}

A short stretch of the northern oval terrace wall of Temple IIb had already been excavated in 1960 in section 31, but without being properly identified (31). In 2004 this piece of wall was re-excavated and shown to be part of the Temple IIb terrace wall. In section 31 the wall (A) delimits the fill of the oval platform of Temple IIb. Onto this piece of wall a semicircular structure was attached (Fig. 20), similar to the oval structure attached to the terrace wall of Temple IIa towards the west (32). The building technique and dimensions correspond to the oval walls of Temples IIa and b in the west: use of uncut stones varying from hand-size to $30 \mathrm{~cm}$ across and laid in clay. The oval structure to the west of the temple had a floor at least $0.5 \mathrm{~m}$ under the assumed surface of the oval platform, and likewise the clayey floor of the semicircular structure was sunk into subsoil sand to level 3.99, more than $1 \mathrm{~m}$ under the 


\section{F. HØJLUND ET AL.}

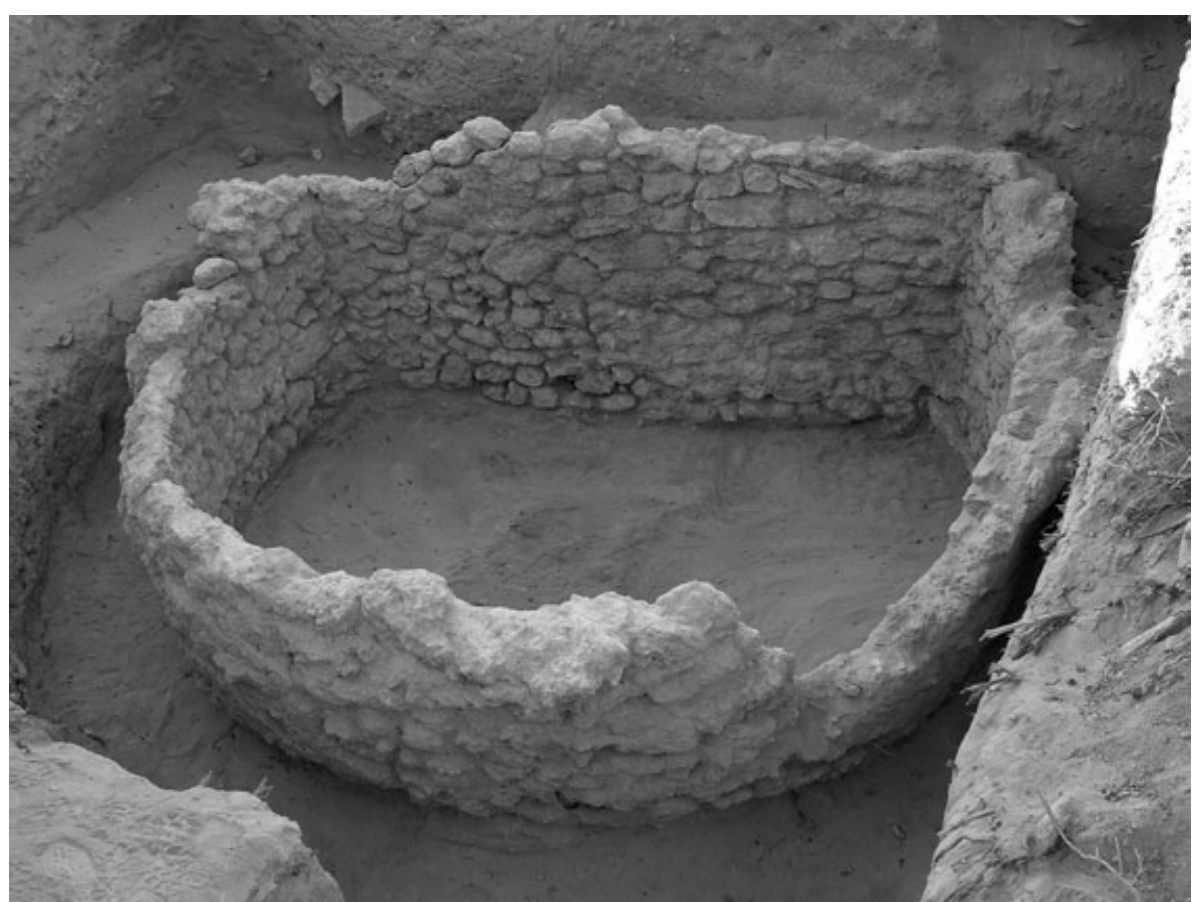

Fig. 20.

Semicircular structure attached to Temple IIb oval wall, from the north (2004).

platform surface. The continuation of the terrace wall both east and west was disturbed and could therefore not be followed in the sections.

The semicircular structure contained clayey sandy fill with animal bones and pottery dating to Temple $\mathrm{IIb}$, e.g. an unusual import from the Indus region, a
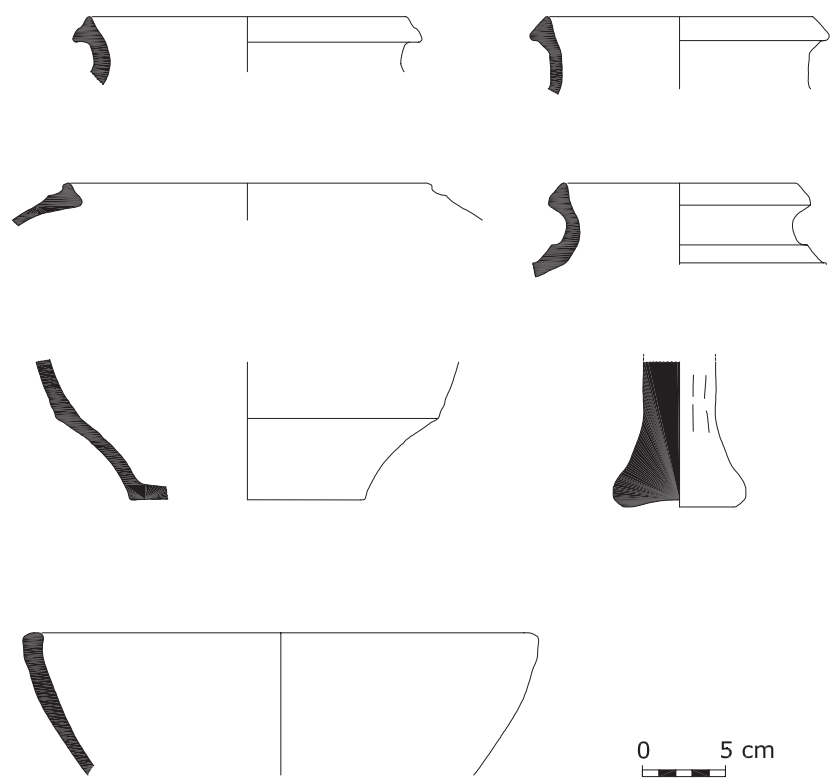

Fig. 21.

Pottery found in semicircular structure. rough-surfaced mould-shaped base (Fig. 21), as well as a fragment of an altar in oolitic limestone (Fig. 22) and a rim sherd from a finely polished stone jar (Fig. 23).

\section{Seal-stamped tokens}

On the surface of the Temple IIb oval platform at level 2.00-2.30 two parallel walls were excavated in 1960, surrounded by ashy layers (33). From this area
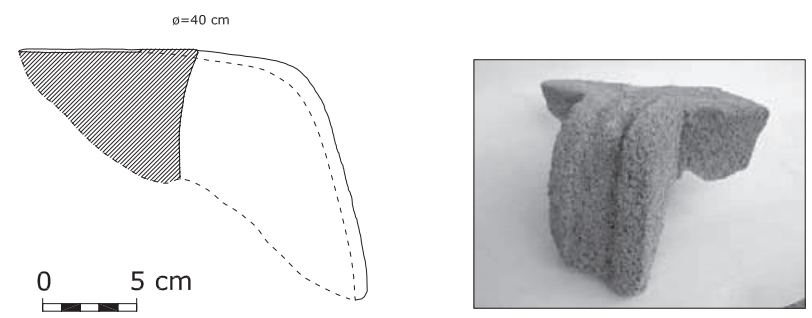

Fig. 22.

Fragment of stone altar.

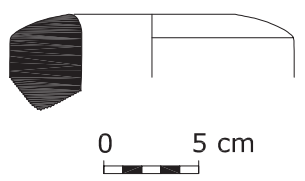

Fig. 23.

Fragment of stone jar. 
came six seal-stamped tokens and from a neighbouring trench to the west stems a further seal-impressed token (34). The same ashy layer occurs as layer 7 in the North-South Section (Fig. 18), and c. $25 \mathrm{~cm}$ above this layer, in layer 4, a seal-impressed token was found $(x 1)$. Another token (x2) was found in the surface layer of the north-south sounding at c. $63 \mathrm{~N}$. Token no. 692x1 (Fig. 24).

Diameter of the obverse $17.5 \mathrm{~mm}$, maximum thickness $7.5 \mathrm{~mm}$, edge thickness $4 \mathrm{~mm}$. Light brown, baked clay. Reverse convex, surface plain, vertical edge.

Obverse: Two standing nude men with legs crossed above the knees. Both of them are looking outward and are grasping a crescent enclosing a big bird between and behind them. Their free hands, with three prominent, pointed fingers, are raised. The space between their elbows and legs is filled with two prominent sun rings.

A very similar motif with two crossed, nude men grasping ritual emblems is present on a bifacial seal from Failaka (35). The design of the hand is exceptional, but known from a seal from Saar Settlement (36). Sun rings are known from more motifs of ritual character in style 1A2-3 from Failaka (37). Birds in crescents are not known from other seal motifs than here, but often crescents or crescent staffs are flanked by birds, which is, however, often the case with other emblems (38).

Token no. $692 x 2$ (Fig. 25).

Diameter of the obverse $17.5 \mathrm{~mm}$, maximum thickness $7.5 \mathrm{~mm}$. Hemispherical token, surface plain. Light brown, baked clay.

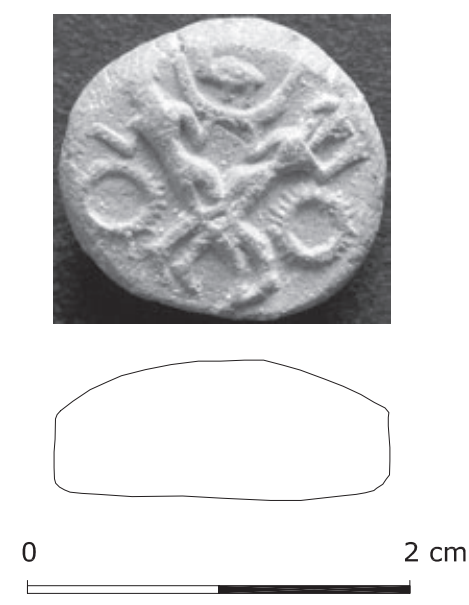

Fig. 24.

Seal-stamped token.
Obverse: The details of the motif have flaked off, leaving only the traces of one horizontal and four vertical, shallow depressions, which resembles the impression on three tokens found earlier at Barbar and one token found at Saar Settlement (39).

Token $692 \times 1$ differs from the previously found tokens from Barbar in its vertical edge, while $692 \times 2$ has the same hemispherical form as the other tokens from Barbar. Both tokens differ, however, from the other tokens from Barbar in their size of only $17.5 \mathrm{~mm}$ in diameter against $20-21 \mathrm{~mm}$ and a height of $7.5 \mathrm{~mm}$ against $10 \mathrm{~mm}$, which is the norm for the others. In view of the great uniformity in size of all the other tokens, it is possible that not only the stamp, but also the size of the tokens bears witness to a different origin (40).

The Temple III pool chamber and the northern foreland The main objective for the sounding north of the temple was to search for a pool chamber related to Temple III. As suggested earlier, the presence of two plinth-stones north of the Temple III platform (41) points to a likely position of a staircase leading down to a pool related to Temple III, in analogy with the plinth-stones along the pool staircase of Temple II (42).

A further analogy which became clear during the 2004 campaign is the presence of a round stone block with a central hole placed just outside the Temple III oval terrace wall and on a line right between the two plinth-stones (Fig. 19.5). This stone can be compared to a structure of similar shape and dimensions placed under the staircase leading down to the Temple II pool, right where the staircase is met by the Temple IIa oval terrace wall (43). The function of these structures is unclear, but Andersen's sugges-

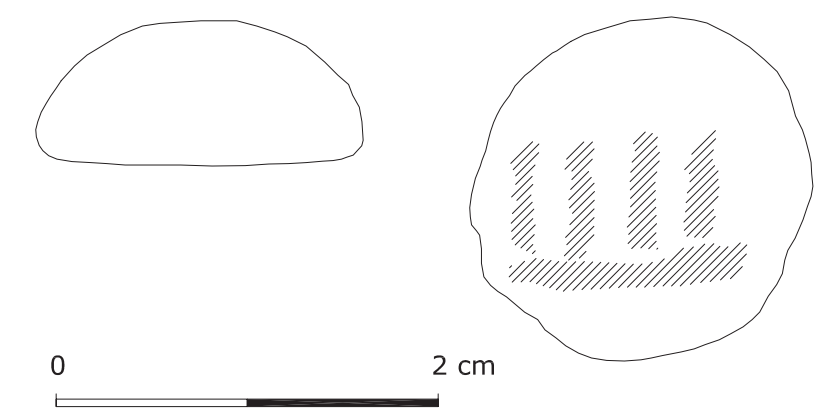

Fig. 25.

Seal-stamped token, eroded. 


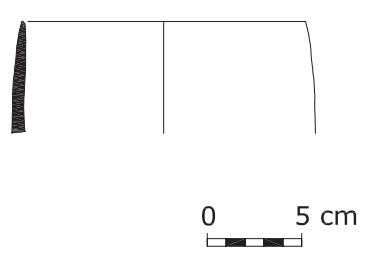

Fig. 26.

Rim sherd of steatite.

tion of an indication mark of a technical nature seems likely.

The excavations in 2004 did not produce any clear-cut evidence for a subterranean pool chamber outside the Temple III oval terrace wall in the area immediately north of the plinth-stones, but the presence of a very large, flat-bottomed pit, discussed below, may perhaps be related to the plundering of an access way to such a structure.

The area north of the temple is characterized by a $2.30 \mathrm{~m}$-thick sequence of horizontal, sandy to clayey layers containing animal bones, charcoal, sherds, etc. (Fig. 18). The sherds dated layer 61 to Temple I/IIa, layer 56 to Temple IIa and layer 51 to Temple IIb. No clear structures were found. In layer 52 was a finely polished rim sherd of grey steatite (Fig. 26), and the clayey layer 56 contained, apart from a lot of animal bones and pottery, a stamp seal:

Stamp seal no. $692 \times 34$ (Fig. 27).

Disc profile concave, grey steatite, white-glazed. On the reverse one groove and four circles. Diameter of the obverse $20 \mathrm{~mm}$, diameter of the boss $14 \mathrm{~mm}$, total height $12 \mathrm{~mm}$, disc height $7 \mathrm{~mm}$.

Obverse: a standing ithyphallic man with his right hand by his waist, holding his phallos between the legs of his partner with his left. She is here, as usual on most of the erotic motifs on the Dilmun seals, depicted with her legs wide apart, grasping her feet and drinking from a tube in a jar. A serpent winds along her left arm. Behind the legs of the man a crescent.

The sexual theme with the individual figures in the same relationship as on the seal here is well represented in Bahrain and is relatively common on Dilmun seals also outside the island, and it occurs in both Arabian Gulf and proto-Dilmun style and in mature Dilmun style (44). The seal in question belongs to the proto-Dilmun group in shape as well as in style: the boss is narrow and has only one diametrical groove, and the design of the heads and faces of both the man and the woman are character-
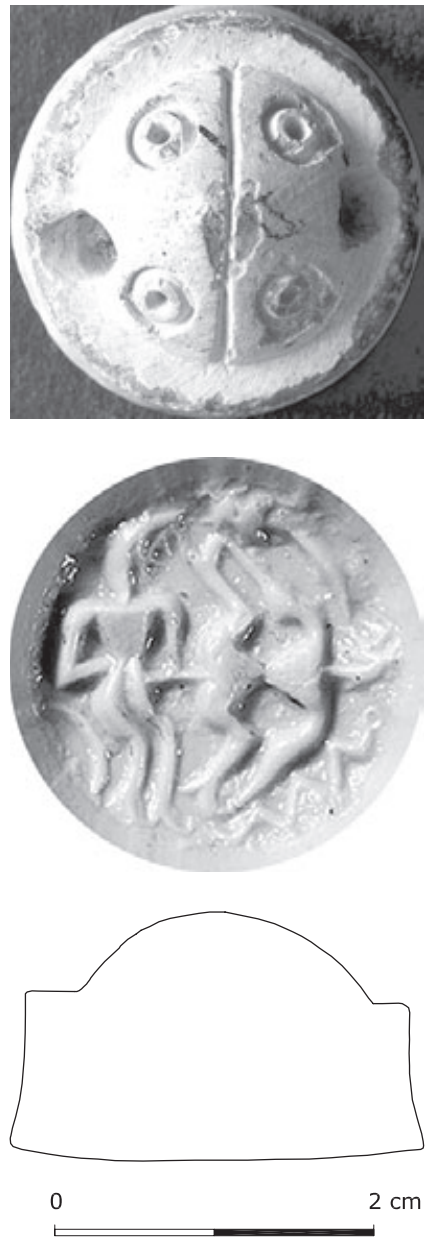

Fig. 27.

Stamp seal in proto-Dilmun style.

istic for proto-Dilmun seals (45). The seal is of special interest because it is the first seal found at Barbar in a Temple IIa context, and this context confirms the dating of the proto-Dilmun seals argued earlier.

The horizontal layers, described above, north of the temple were cut by a huge pit with steep sides and a flat bottom (Fig. 18.40-44, 47-48), originating at or above level c. 3.00, i.e. cutting the Temple IIb levels and ending in levels 4.55 to 4.85 . Along the North-South Section the pit measures only c. $4.75 \mathrm{~m}$, from c. $67-72 \mathrm{~m} \mathrm{~N}$, but towards the southeast it widened out and could be followed for $12 \mathrm{~m}$ and towards the east for $7 \mathrm{~m}$ without its limits being found (Fig. 19). Because of modern structures it was difficult to follow towards the west.

The pit was filled with horizontal layers of homogeneous yellow to grey-brown sand with some scattered stones and plaster rubble; at level 3.50-3.60 

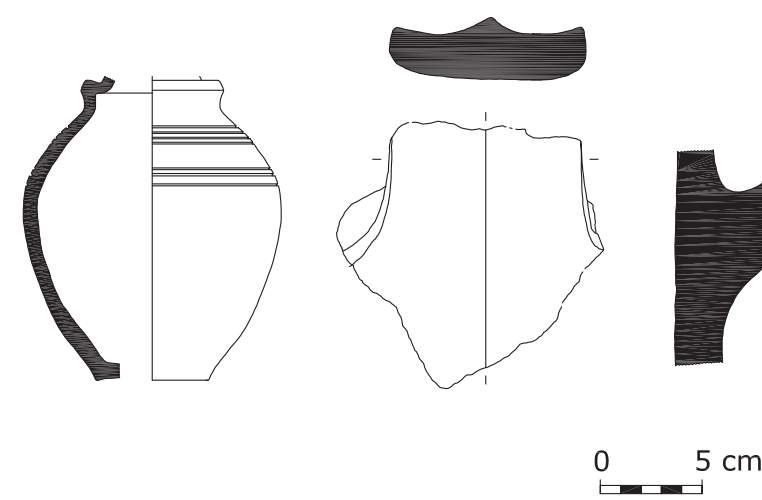

Fig. 28.

Pottery from the huge pit north of the temple: jar in light brown ware with yellowish surface and handle in hard-fired, light brown ware.

a $2-10 \mathrm{~cm}$ thick shell layer was noted all over the pit (also in Fig. 18.40). The few sherds, mostly sidesherds, found in the pit date to the Sasanian-Islamic period (Fig. 28) (46).

In the old excavations at the Barbar Temple large pits could normally be explained as traces of stone plundering. And with the even and almost horizontal bottom of this pit, it is hardly evidence for a search operation! It seems that something constructed of valuable stone blocks may actually have been standing in this area, and the possible removal of such stones can be dated by the finds of pottery to the Sasanian-Islamic period, the main period of stone plundering at the temple (47). With the level of the bottom of the pit at c. 4.80, it is hardly deep enough to have been the well chamber itself, but perhaps a staircase leading down from the temple platform along a route which escapes us at the moment. Further excavation is needed to solve this question.

\section{Conclusion}

The location in 2004 of the oval platform wall of Temple III is a reminder not to put too much emphasis on the missing structures of this phase of the temple compared to the earlier phases. Since Temple III was the uppermost one and therefore the most easily accessible to the stone plunderers, it is no wonder that so little has survived. There is reason to believe that future investigations may uncover further evidence concerning phase III of the Barbar Temple, so that its relation to the earlier temple phases may be elucidated.

\section{The Northeast Temple (691)}

The well-chamber

About $40 \mathrm{~m}$ northeast of the Barbar Temple lies another temple which was plundered down to its foundations, a c. $24 \times 24 \mathrm{~m}$ square, $25-30 \mathrm{~cm}$-thick layer of stone and plaster, which originally carried a platform on top of which a building had been standing. The Northeast Temple was partly excavated in 1956 and 1961, and in the centre of the plaster foundation a large broach was noted, but only sounded to a depth of c. $1.5 \mathrm{~m}$ (48).

In 2004 the complete outline of this broach was uncovered and measured to $c .6 .25 \times 2.4 \mathrm{~m}$. The edge of the plaster layer around the broach is irregular and unfinished and appears to have been broken up, and numerous marks from a pick-axe along the edge clearly show how this was done.

The 1956 and 1961 excavators suggested that this hole might contain the plundered remains of a structure built of well-dressed limestone ashlars, probably a shaft-stairway leading down to a wellchamber such as that found at Umm as-Sujur (49). During the 2004 campaign this was proved to be the case, but the plundering of the monument was so effective that not a single ashlar was left in situ.

The hole was emptied of its contents of inclined layers of sand, stone and plaster rubble that had filled it after the plundering. In 1956 some finely cut limestone blocks were found lying ex situ in the upper part of the hole, and in 2004 a small number of similar well-dressed stones and fragments of such were found in the filling. The emptying of the hole down to a depth of $3.92 \mathrm{~m}$ below the plaster foundation revealed in the subsoil sand the impression of a narrow staircase shaft sloping down towards the east to a rectangular chamber with a small well-hole in the floor (Fig. 29).

The slope of the staircase shaft was irregular, leaving some plateaus, where the foundations for the actual steps would have been built (Figs 29-30). The clay layer 6 and the plaster-like layer 5 seen in the section, and the four stones found in situ in brown clayey sand, are probably part of such foundations. It is estimated that there were c. 11 steps from the plaster foundation to the floor of the chamber, each step measuring $40 \mathrm{~cm}$ deep and $25 \mathrm{~cm}$ high. The width of the staircase shaft is c. $1 \mathrm{~m}$, therefore with flanking side-walls of 15-20 cm thick ashlars, which are known from the 


\section{F. HØJLUND ET AL.}

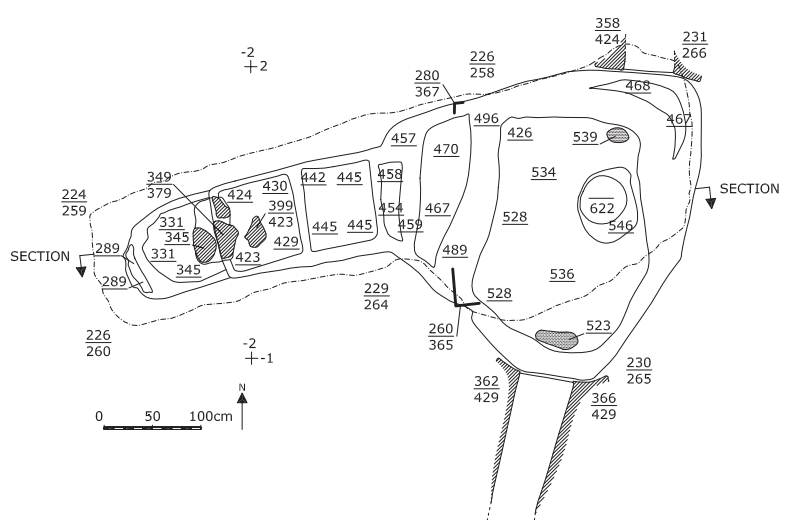

Fig. 29.

Plan of plundered well-chamber in the Northeast Temple.

staircase leading to the pool in the Barbar Temple, this leaves a stair width of $60-70 \mathrm{~cm}$.

The southwest and northwest corners of the chamber were preserved in the original fill layer, sharply defined and right-angled, and interpreted as impressions of ashlars (Fig. 29). The chamber extends c. $50 \mathrm{~cm}$ further to the south than the present edge of the plaster layer, and indeed the whole chamber, apart from an entrance into the staircase, must have been roofed over. The well-hole in the bottom of the chamber is roughly circular, with a diameter of $80 \mathrm{~cm}$ in the upper part.

In the north and south walls of the hole, $1.2 \mathrm{~m}$ above the bottom, almost identical channels emerged (Fig. 29). The channels are dug into the subsoil sand. The walls of the channels are built of uncut stone set in clay, sometimes reinforced with bitumen, and the roofs consist of uncut stones set in plaster (Fig. 31). The channels were almost com-

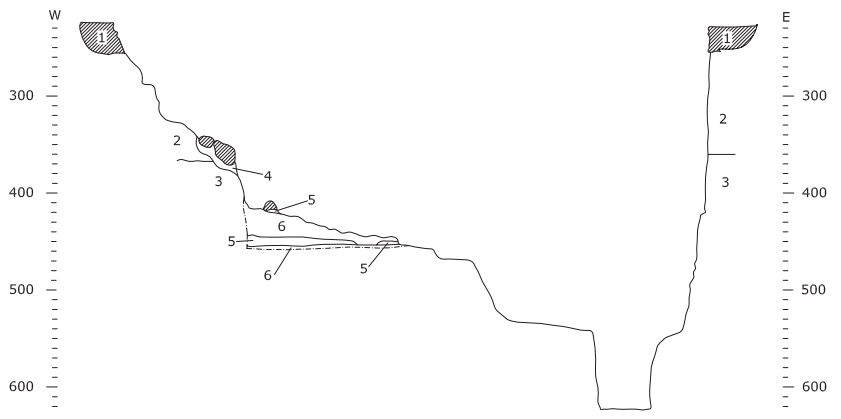

Fig. 30 .

Section through plundered well-chamber in the Northeast Temple. 1: foundation of stone and plaster. 2: yellow-brown gravelly sand with many small stones and a little pottery and bones. 3: yellow sterile sand, subsoil. 4: brown clayey sand. 5: hard, plasterlike sand with small stones. 6: brown clay. pletely filled up with horizontal layers of sand and clay, some of them containing many small bits of bitumen. Similar bits of bitumen were found in two places on the chamber floor (Fig. 29), perhaps indicating where the channels had their outlet. The south channel was emptied to a depth of $1.4 \mathrm{~m}$ and found to slope towards the chamber by $c .10 \mathrm{~cm}$ over this short distance. The north channel was also found to slope towards the chamber.

In the trenches dug south of the plaster foundation (see below) no continuation of the south channel was found.

The interpretation of the plundered structure as a well accessed by a staircase seems straightforward. We must imagine that subsoil water appeared in the well-hole, and at least occasionally the water level stood high in the chamber. This is indicated by the fact that the sides of the hole in the subsoil sand, up to level c. 4.10, were covered by a thin layer of brown, plastic clay, such as would be deposited in a pool of still-standing water, which would penetrate all cracks and hollows behind any stone construction. The two channels leading into the well chamber have presumably created the extra possibility of leading water into the well chamber from elsewhere, a feature that is also found at the pool of the Barbar Temple (50) and which may perhaps be explained by seasonal and yearly variations in the water table.

During the cleaning of the plaster foundation in the area of the southeastern corner of the inner terrace wall (51), the upper layer of the plaster layer was brushed away and revealed the impression of a $4 \mathrm{~m}$-long cord, parallel to the southern side of the monument, crossed by two other cord impressions over a distance of $30 \mathrm{~cm}$, running parallel with the eastern side of the monument. The cords may perhaps have formed guidelines for the construction of the monument (52).

During the cleaning of the east side of the plaster foundation, where the edge is made of cut limestone blocks (53), one of these blocks proved to be a phallic cult-stone of oolitic limestone (Fig. 32) (54). Its upper side measures $26.3 \mathrm{~cm}$ across and is slightly concave with a depression of $0.6 \mathrm{~cm}$. The upper part, $39 \mathrm{~cm}$, is in some places smooth, without cut-marks, otherwise it is eroded. The lower part, $22 \mathrm{~cm}$, is roughly cut, as if intended to be inserted into a base (Fig. 33). Below this stone a carnelian bead was found 


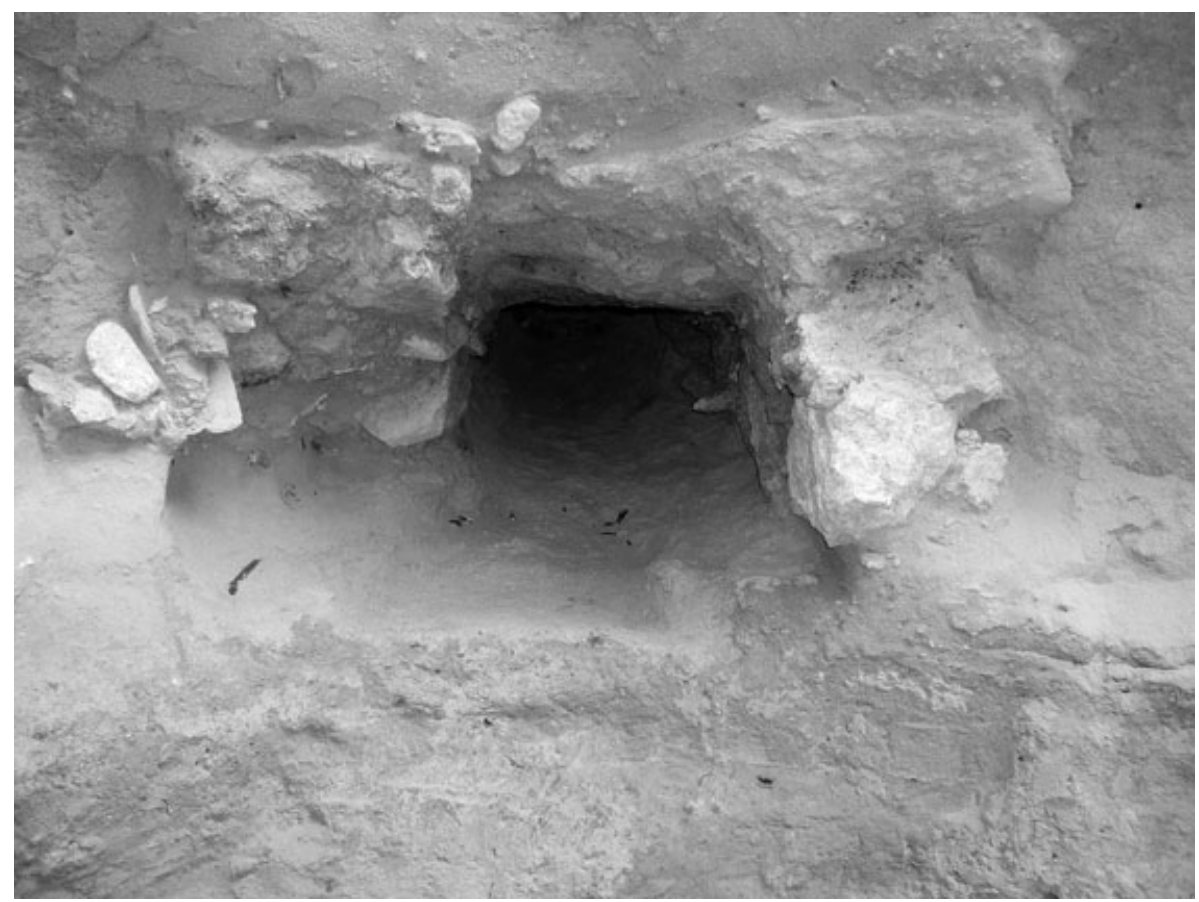

Fig. 31.

South channel emerging in well-chamber of Northeast Temple, from the north (2004).

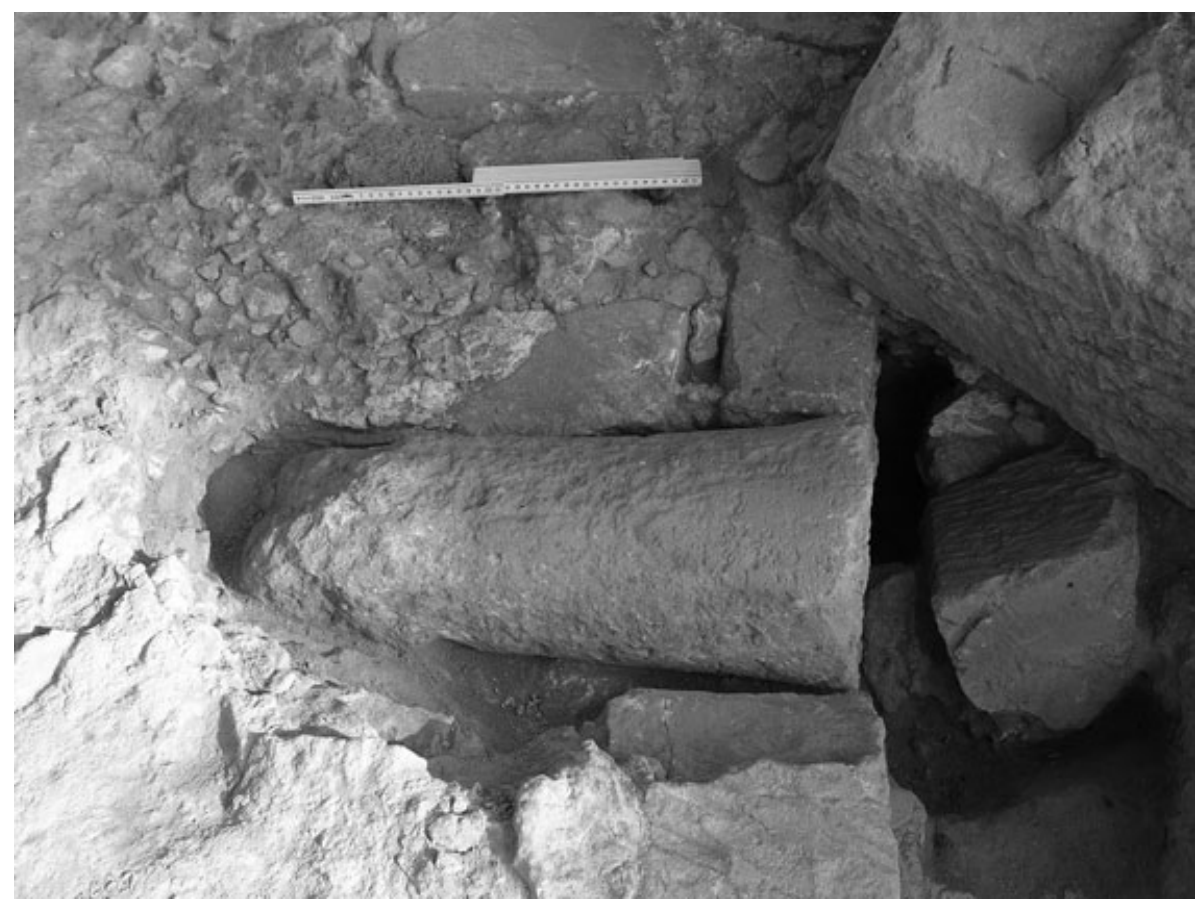

Fig. 32.

Phallic cult-stone in situ, secondarily used, from the south (2004). 


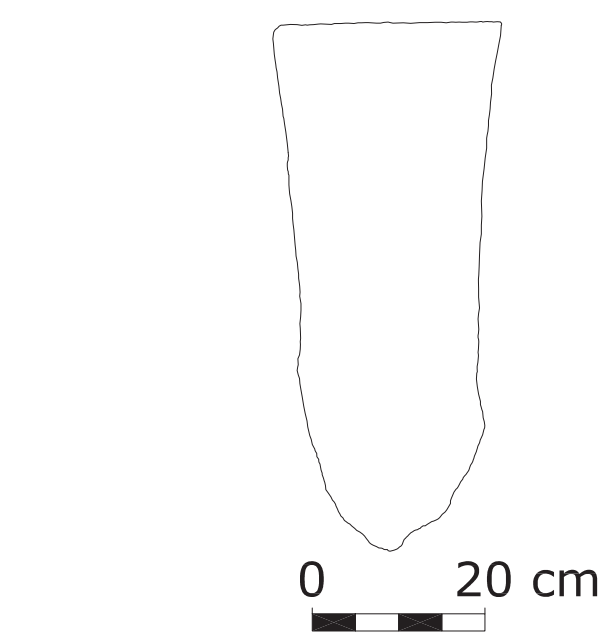

Fig. 33.

Phallic cult-stone.

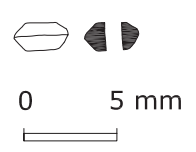

Fig. 34.

Carnelian bead.

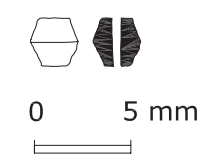

Fig. 35.

Carnelian bead.

(Fig. 34). A similar bead was found, also during cleaning of the plaster foundation, $0.5 \mathrm{~m}$ east of the southeast corner of wall C1 (55) (Fig. 35). Both beads are irregularly biconical, with coarse grindingfacets.

\section{A temenos wall?}

Soundings in 1961 brought some, in the words of the excavators, 'restricted' and 'insecure' indications for a lower temple platform below and around the upper platform built on the $24 \times 24 \mathrm{~m}$ plaster layer described above (56). According to this view, the terrace wall of a lower platform should lie 11-12 m south of the upper platform, but during the excavations in 2004 no evidence for a terrace wall was found in this area.

In several trenches south of the upper platform there was evidence of a compact, 10-30 cm-thick layer of oolitic limestone chippings, i.e. residue from the final shaping of limestone ashlars, but generally much degraded, sometimes into something which looked like crushed plaster, which was, indeed, the description this layer received in 1956 (57). These chippings were probably produced during the shaping of limestone ashlars for the terrace wall of the upper temple platform, for the building that stood upon it and for the well-chamber and staircase it enclosed. Oolitic limestone chippings are commonly found in excavations at Barbar and are normally sharp-edged and well preserved. The degradation so characteristic of this layer of chippings must be due to the layer having been exposed over a prolonged period of time, and we are probably dealing with the ground level of the area surrounding the Northeast Temple.

The layer is at level c. 2.40 close to the central temple platform and falls gently towards the south, probably because of the general development of the terrain, to level c. 2.50 in $-15 \mathrm{~m} \mathrm{~S}$, and c. 2.95 in $-22 \mathrm{~m} \mathrm{~S}$, from where it can be followed towards the west to $-8.75 \mathrm{~W}$, where it rises to $c .2 .70$.

North of the upper platform the layer of chippings can be followed for almost $9 \mathrm{~m}$ and is here described as a 'powdery plaster-like mass' (58). Near the platform it is at level c. 2.40 and furthest to the north it has descended to level 3.00.

The gently sloping surface of the layer of chippings south of the upper temple platform does not indicate the presence of a lower platform, but at 0/-15 m S a $1.70 \mathrm{~m}$-wide and 35-40 cm-high construction of ashlars and hand-sized fragments of oolitic limestone (Fig. 36.3-4) is built directly on top of the layer of chippings (Fig. 36.5). In 1956 this construction was cut half a metre further east by a north-south section and described as masonry consisting of stone and plaster (59). This could possibly be the lower part of a wall enclosing the temple precinct, and it is notable that a similar phenomenon was observed east of the temple with approximately the same distance, c. $6 \mathrm{~m}$, to the upper platform (60).

No finds were associated with the layer of limestone chippings or with the possible enclosure wall.

Several north-south going sections crossing the c. $-15 \mathrm{~m} \mathrm{~S}$ line show that before the layer of chippings was formed a large pit was dug into the yellow subsoil sand to level c. 3.60 and filled with brownish gravel (Fig. 36.6 and 9). The southern 


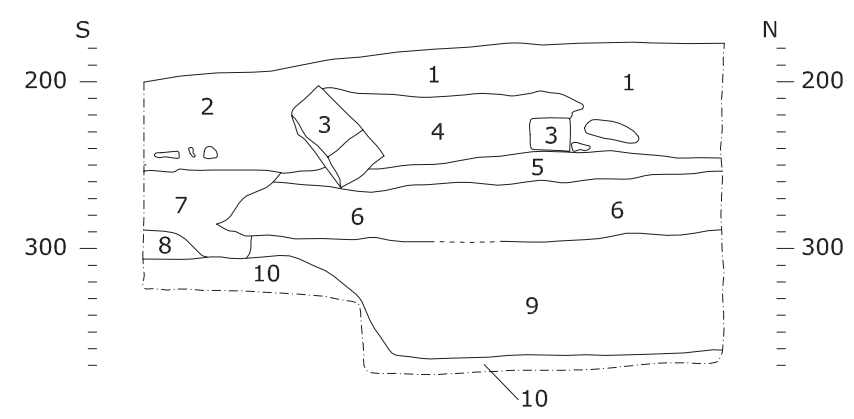

Fig. 36.

Section through foundation of possible temenos wall around Northeast Temple. 1: brown sand with many small stones and some sherds. 2: brownish gravel with some small stones and plaster rubble. 3: limestone ashlars. 4: hand-sized oolitic limestone chippings in fine yellow-brown sand. 5: small oolitic limestone chippings, much degraded. 6: brownish gravel. 7: brownish gravel with charcoal particles, plaster rubble and oolitic limestone chippings. 8: dark yellow sand. 9: very compact, brown gravel with charcoal particles and some small stones. 10: yellow sand, subsoil.

termination of this pit seems to coincide with the possible wall enclosing the lower temple precinct described above. In the central well-chamber hole the same stratigraphy can be seen in layer 2 with base level in 3.60 (Fig. 30) (61), indicating that this pit may have covered all of the temple area. The few sherds found in the pit compare well with pottery found in the platform fill (62).

\section{The house}

Nine metres south of the upper platform and c. $3 \mathrm{~m}$ south of the possible enclosure wall, described above, the remains of a house were uncovered in two trenches in the shape of large portions of a fine plaster floor which seems to have been constructed directly on the layer of limestone chippings, described above (Fig. 37). The floor has a northeastsouthwest orientation and evenly finished edges towards the northwest, northeast and southeast (Fig. 38.4). It is $3.75 \mathrm{~m}$ wide and at least $10.25 \mathrm{~m}$ long, but the southwestern edge has not been located.

The evenly finished edges of the floor look as if the plaster was applied up to a vertical border such as a wall that has now disappeared. In the section through the house, the floor plaster towards the southeast continues into a thin, $30 \mathrm{~cm}$-high, vertical layer of plaster, followed c. $60 \mathrm{~cm}$ further southeast by a similar vertical plaster layer (Fig. 39.9) apparently the inside and outside coating of an ashlar wall later plundered. North and east of the plaster floor, a c. $70 \mathrm{~cm}$-wide band seems to bear witness to the existence of this wall (Fig. 38.3).

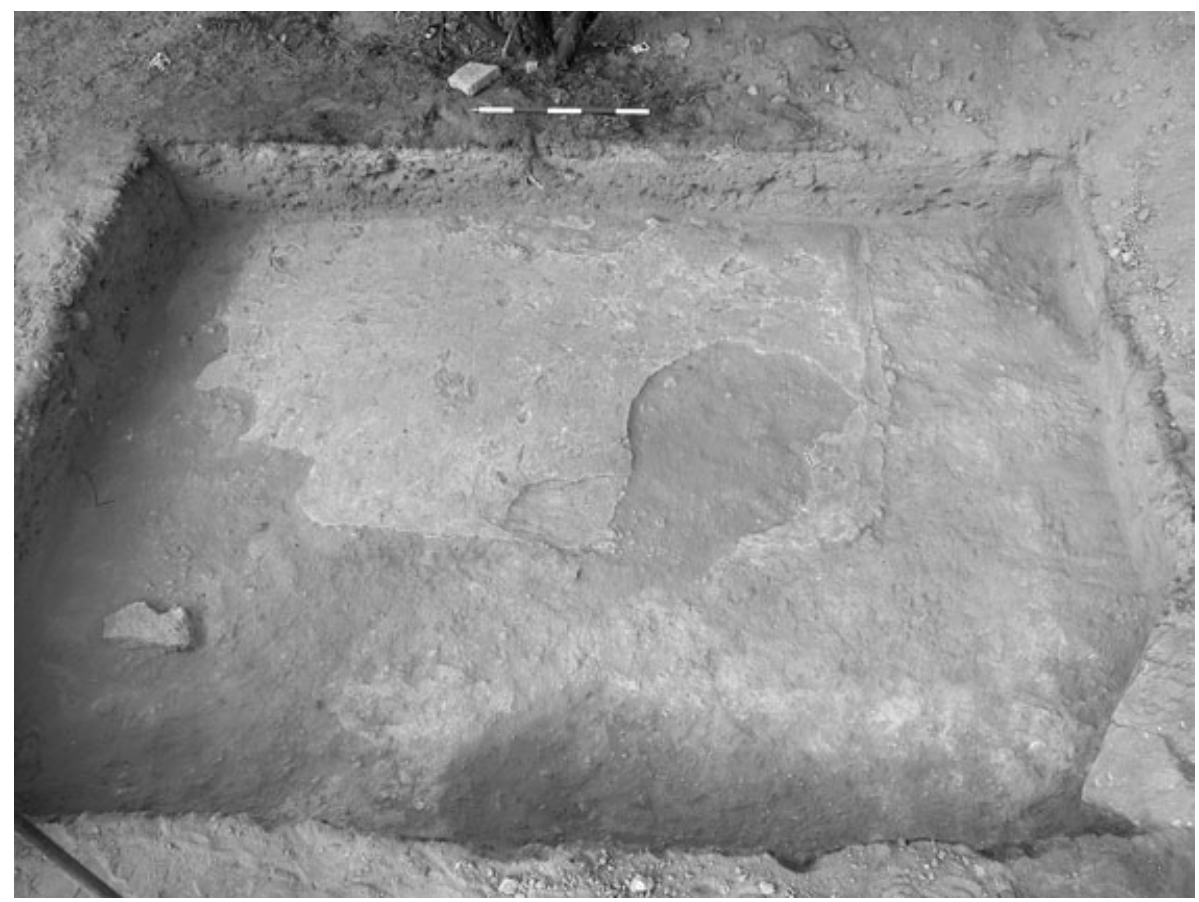

Fig. 37.

Plaster floor south of the Northeast Temple, from the northeast (2004). 


\section{F. HØJLUND ET AL.}

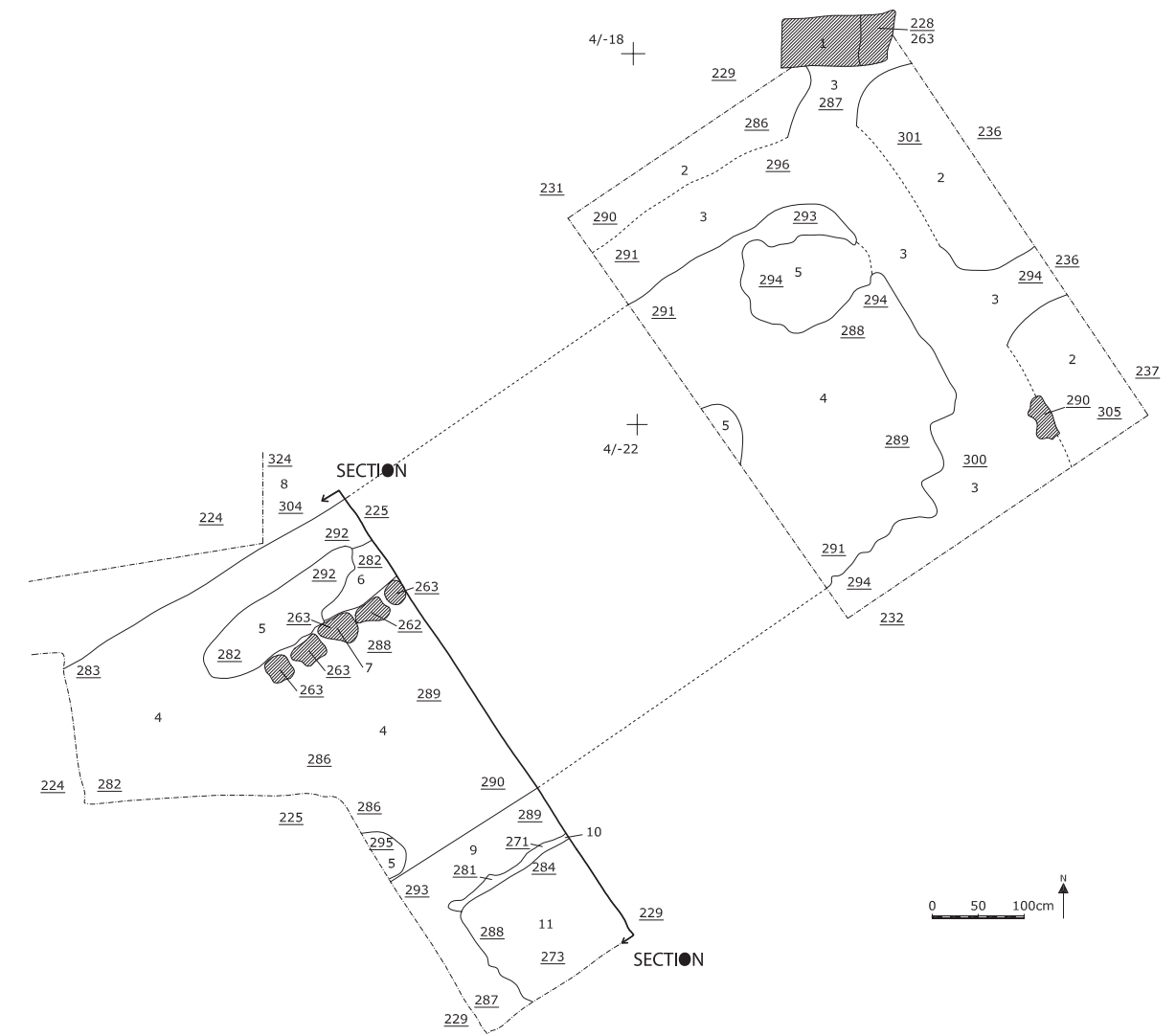

Fig. 38.

Plan of the house south of the Northeast Temple. 1: limestone ashlar. 2: yellow-brown sand with many small stones, some bones and potsherds. 3: hard whitish-yellow sand. 4: plaster floor. 5: disturbance of 4. 6: hard clay covering 4. 7: five stones on 4. 8: stones and plaster rubble. 9: hard yellowish-grey sand with many small stones and plaster rubble. 10: vertical plaster ridge. 11: hard yellowish-grey sand with large, up to $40 \mathrm{~cm}$, uncut stones.

A few holes were visible in the plaster floor (Fig. 38.5), possibly later disturbances. One metre from the northwest side of the floor was a row of five, uncut stones placed on the floor, and in the section a new course was visible, made of plaster

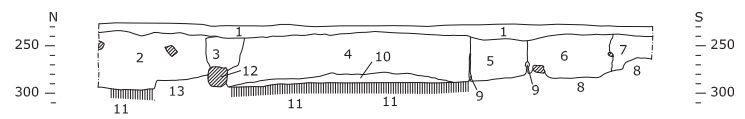

Fig. 39.

Section through the house south of the Northeast Temple. 1: brown-greyish soil. 2: brown-greyish sand. 3: uncut stones the size of a hand set in plaster, wall on row of stones (12). 4: browngreyish sand. 5: brown-yellowish clayey sand. 6: brown-yellowish clayey sand with many small stones. 7: as 6, but without small stones. 8: compact brown soil with plaster rubble, oolitic limestone chippings and hand-to-head-size stones. 9: vertical plaster. 10: yellow-whitish soil with many bones and potsherds. 11: plaster floor. 12: stones in a row, foundation for wall (3). 13: hard clay covering 11. and smaller stones (Fig. 39.3). On the floor south of this wall was a 10-20 cm-thick layer of yellowwhitish clayey soil.

In the soil above the plaster floor potsherds were plentiful in both trenches and almost only from necked storage jars with late variants of the triangular rim, with a few rims from bowls and hole-mouth vessels, plus one rippled shoulder sherd of Failaka type 47 and one scored shoulder sherd of Failaka type 48 (Fig. 40) (63). The ware is almost only of type 2 (64), side-sherds are either smooth or low-ridged, bases are either marked of type B40 or simple, flattened of type B43 (65). Altogether, the assemblage is very similar to one (517.ARU) found in a 1961 sounding, also located outside the central plaster platform of the Northeast Temple (66), and as here with a variation of triangular rims that characterizes a late phase of Qala'at al-Bahrain period II till now only rarely 

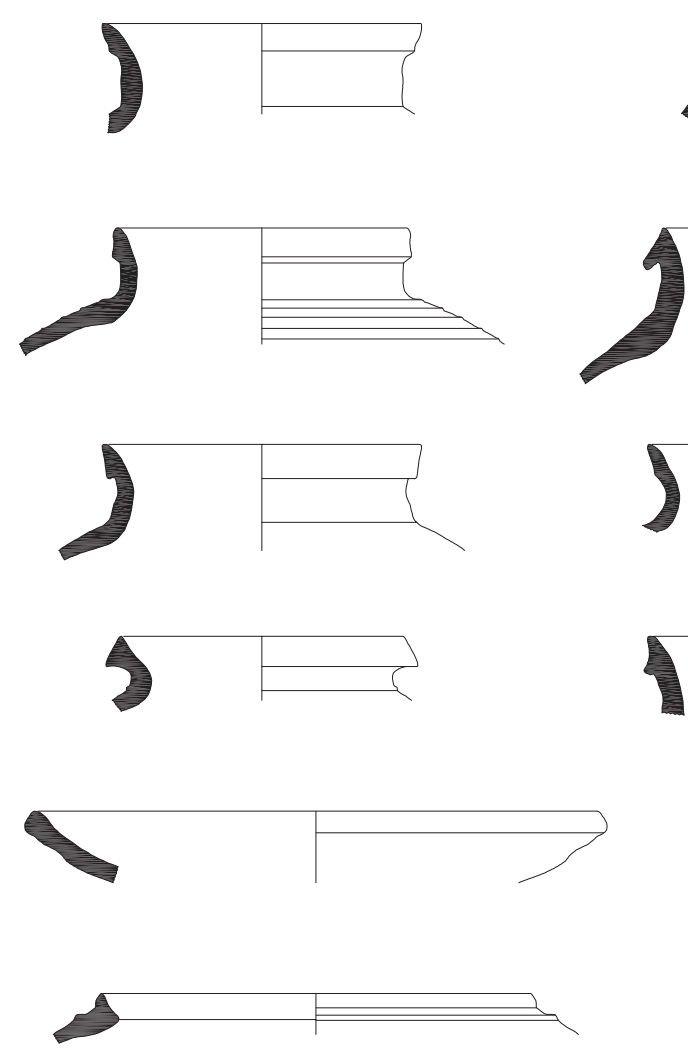
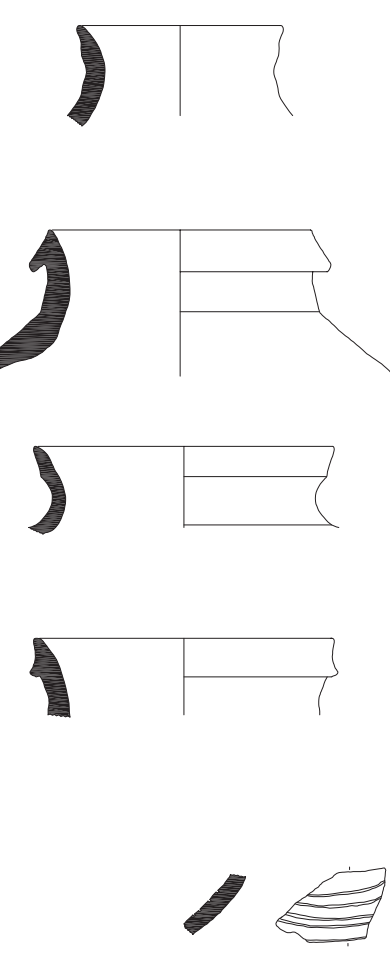

Fig. 40.

Pottery found on the floor of the house south of the Northeast Temple.
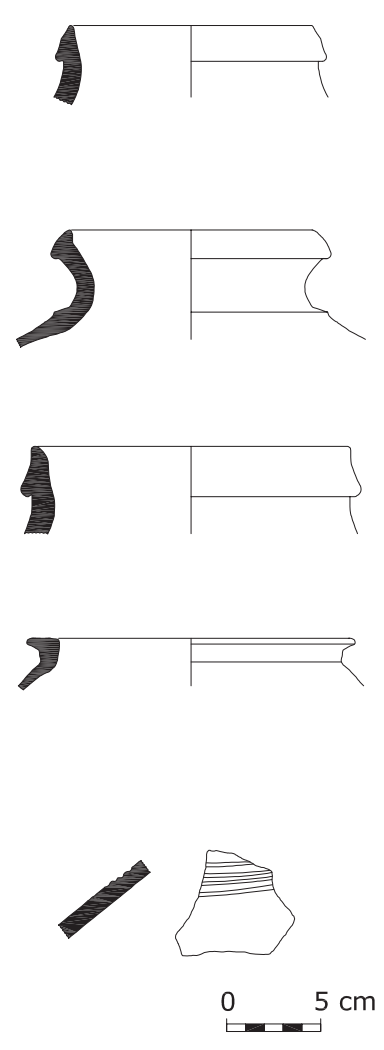

found in Bahrain, but well represented in Failaka as period 2B (Fig. 6) (67). This accords well with the sparse finds from the old excavations indicating that the Northeast Temple postdates Barbar Temple IIb (68).

\section{References}

1. Andersen HH \& Højlund F. The Barbar Temples, vols 1-2. Aarhus: JASP, 48: 2003.

2. For their generous hospitality and efficient assistance our warm thanks go to the Bahrain Minister of Information, HE Mr Nabil bin Yacoub AlHamer, Undersecretary Mr Mahmoud Al-Mahmoud, Assistant Undersecretary Shaikha Mai Al Khalifa, Acting Director of Archaeology \& Heritage Mr Khaled Al-Sendi, and Supervisor of Archaeology Mr Abdelkarim Al-Moft. For permission to excavate in the private garden north of the temple we are grateful to Mr Isa bin Ali and his sons. The excavations were carried out by Pernille Bangsgaard, Jesper Hansen, Niels Haue, Dorthe Danner Lund and Flemming Højlund, assisted by twenty Bahraini labourers. The excavations were supported by the Carlsberg Foundation, the University of Aarhus, the University of Aarhus Research Foundation, and the Ministry of Information of the Kingdom of Bahrain. Poul Kjærum dealt with the stamp seals and the tokens. The English was revised by Peter Crabb. Karsten Mikkelsen digitized the drawings. The excavations in 2004 are registered at the Oriental Department at Moesgaard Museum as nos 691-693.

3. Andersen \& Højlund, The Barbar Temples 1: 147-151, Figs 185-201, 2: plan 6:4, 6, 7 and 9.

4. Cf. Andersen \& Højlund, The Barbar Temples 1: 233-241.

5. Andersen \& Højlund, The Barbar Temples 1: Fig. 221.
6. Andersen \& Højlund, The Barbar Temples 1: 147, Fig. 250, 2: sections 13.G and 33.G.

7. Andersen \& Højlund, The Barbar Temples 1: Figs 185-200.

8. Andersen \& Højlund, The Barbar Temples 1: 147, 2: section 33.G.

9. Andersen \& Højlund, The Barbar Temples 2: Plan 6:2 and 36.

10. Andersen \& Højlund, The Barbar Temples 2: Section 33.F (the door), section 33.K, Plans 6.10 (the wall) and 6.11 (the threshold).

11. Andersen \& Højlund, The Barbar Temples 1: 185, 2: Plan 7:25.

12. Cf. Andersen \& Højlund, The Barbar Temples 1: 233-241, Figs 463-518.

13. Andersen \& Højlund, The Barbar Temples 1: 327.

14. Frifelt K. Islamic Remains in Bahrain. Aarhus: JASP, 37: 2001: Figs 22-24. 


\section{F. HØJLUND ET AL.}

15. Andersen \& Højlund, The Barbar Temples 1: 185, Fig. 235.

16. Andersen \& Højlund, The Barbar Temples 1: 175-185.

17. Carried out by Niels Breiner of the Institute of Geology, Aarhus University.

18. Andersen \& Højlund, The Barbar Temples 2.

19. Kjærum P. Stamp-seals, seal impressions and seal blanks. In: Højlund F \& Andersen HH. Qala'at al-Bahrain vol. 1. The Northern City Wall and the Islamic Fortress. Aarhus: JASP, 30/1, 1994: nos 18, 19, 20, 22. Crawford H. Early Dilmun Seals from Saar. Archaeology International: Stoke Saint Milborough, 2001: no. 4361:01.

20. Andersen \& Højlund, The Barbar Temples 1: $323 \mathrm{ff}$.

21. Andersen HH. The Barbar Temple: stratigraphy, architecture and interpretation. BTAA 1986: 177. Andersen \& Højlund, The Barbar Temples 1: 187.

22. Andersen \& Højlund, The Barbar Temples 1: Fig. 14, 2: plan 8.3-4.

23. Andersen \& Højlund, The Barbar Temples 2: Main section: A and Plan 5.2.

24. Andersen \& Højlund, The Barbar Temples 1: 131, 2: Plans 3.46 and 5.1.

25. Andersen \& Højlund, The Barbar Temples 2: Main Section: A, Section 30.A.

26. Andersen \& Højlund, The Barbar Temples 1: 187.

27. Andersen \& Højlund, The Barbar Temples 2.

28. Andersen \& Højlund, The Barbar Temples 1: Fig. 243.

29. Andersen \& Højlund, The Barbar Temples 2: Section 31:2-3.

30. Andersen \& Højlund, The Barbar Temples 1: Fig. 222, 2: Plan 6.60.

31. Andersen \& Højlund, The Barbar Temples 2: Section 31.A.

32. Andersen \& Højlund, The Barbar Temples 2: Plan 3.52-53.
33. Andersen \& Højlund, The Barbar Temples 1: Figs 182-183, 2: Section 31.8-10.

34. Kjærum P. Stamp Seals and Seal Impressions. In: Andersen \& Højlund, The Barbar Temples 1: 300-305.

35. Kjærum P. The Stamp and Cylinder Seals. Plates and Catalogue Descriptions. Failaka/Dilmun. The Second Millennium Settlements 1:1. Aarhus: JASP, 17.1: 1983: no. 337.

36. Crawford, Early Dilmun Seals from Saar: no. 5168:01.

37. E.g. Kjærum, Stamp and Cylinder Seals: $\operatorname{nos} 25,31,71$.

38. E.g. Kjærum, Stamp and Cylinder Seals: nos 97, 117, 150, 247 and 131.

39. Kjærum, Stamp Seals and Seal Impressions: 303, Figs 783-84, 787.

40. Kjærum, Stamp Seals and Seal Impressions: $302 \mathrm{ff}$.

41. Andersen \& Højlund, The Barbar Temples 1: 326, Figs 242-245, 2: plan 8.3-4.

42. Andersen \& Højlund, The Barbar Temples 1: Fig. 203, 2: Plan 6.47-54.

43. Cf. Andersen \& Højlund, The Barbar Temples 1: 140 and 2: Plan 5.4 with 1: 165, 2: plan 6:43, and section 33:O.

44. Kjærum, Stamp-seals, seal impressions and seal blanks: 331f, 345f. Kjærum, Stamp Seals and Seal Impressions: 298ff, 303f.

45. E.g. Al-Sindi K. Dilmun Seals. Manama: State of Bahrain, 1999: nos 45 and 47.

46. Oral comm. from S.F. Andersen who examined the sherds in the field.

47. Andersen SF \& Kennet D. Sasanian and Islamic Pottery. In: Andersen \& Højlund, The Barbar Temples 1: 307-10.

48. Andersen \& Højlund, The Barbar Temples 1: 199-208, 2: Plan 10.

49. Andersen \& Højlund, The Barbar Temples 2: 35-45. Konishi MA. Legendary Spring and the Stepped Wells of 2000 B.C., Bahrain - from the excavations at 'Ain Umm es-Sujur. Lahore Museum Bulletin 9/1: 1996: 81-93.
50. The two similar well-chambers at Umm as-Sujur are also connected to a subterranean channel and an open channel respectively, although it is difficult to judge the direction of their inclinations from the plans, cf. Konishi, Legendary Spring: Figs 3-5.

51. Andersen \& Højlund, The Barbar Temples 2: Plan 10.B.

52. Andersen \& Højlund, The Barbar Temples 1: 204-208.

53. Andersen \& Højlund, The Barbar Temples 1: 202, Fig. 258.

54. For this group of objects, see Andersen \& Højlund, The Barbar Temples 2: 47-49.

55. Andersen \& Højlund, The Barbar Temples 2: Plan 10.

56. Andersen \& Højlund, The Barbar Temples 1: Fig. 265, 2: Sections 34.F and 35.3.

57. Andersen \& Højlund, The Barbar Temples 2: Section 35.8 .

58. Andersen \& Højlund, The Barbar Temples 2: Section 35.18 .

59. Andersen \& Højlund, The Barbar Temples 2: Section 35.F.

60. Andersen \& Højlund, The Barbar Temples 2: Section 34.G.

61. Cf. Andersen \& Højlund, The Barbar Temples 2: Section 34.2-3.

62. Andersen \& Højlund, The Barbar Temples 1: Figs 600-615.

63. Højlund, F. The Bronze Age Pottery. Failaka/Dilmun. The Second Millennium Settlements 2. Aarhus: JASP, 17/2: 1987.

64. Andersen \& Højlund, The Barbar Temples 1: 210.

65. Højlund \& Andersen, Qala'at al-Bahrain vol. 1.

66. Andersen \& Højlund, The Barbar Temples 1: Figs 633-656.

67. Højlund, The Bronze Age Pottery. Andersen \& Højlund, The Barbar Temples 1: 210.

68. Andersen \& Højlund, The Barbar Temples 1: 249. 
Copyright of Arabian Archaeology \& Epigraphy is the property of Blackwell Publishing Limited. The copyright in an individual article may be maintained by the author in certain cases. Content may not be copied or emailed to multiple sites or posted to a listserv without the copyright holder's express written permission. However, users may print, download, or email articles for individual use. 